\title{
Improved global simulations of gross primary product based on a new definition of water stress factor and a separate treatment of C3 and C4 plants
}

\author{
Hao Yan ${ }^{\mathrm{a}, \mathrm{l}, *}$, Shao-qiang Wang ${ }^{\mathrm{b}}$, Dave Billesbach ${ }^{\mathrm{c}}$, Walter Oechel ${ }^{\mathrm{d}}$, Gil Bohrer ${ }^{\mathrm{e}}$, \\ Tilden Meyers ${ }^{\mathrm{f}}$, Timothy A. Martin ${ }^{\mathrm{g}}$, Roser Matamala ${ }^{\mathrm{h}}$, Richard P. Phillips ${ }^{\mathrm{i}}$, \\ Faiz Rahman ${ }^{\mathrm{j}}$, Qin $\mathrm{Yu}^{\mathrm{k}}$, Herman H. Shugart ${ }^{1}$ \\ a National Meteorological Center, China Meteorological Administration, Beijing 100081, China \\ ${ }^{\mathrm{b}}$ Institute of Geographic Sciences and Natural Resources Research, Chinese Academy of Sciences, Beijing 100101, China \\ ${ }^{\mathrm{c}}$ Department of Biological Systems Engineering, University of Nebraska, NE 68583-0726, USA \\ d Biology Department, San Diego State University, CA 92182-4614, USA \\ e Department of Civil, Environmental and Geodetic Engineering, Ohio State University, $\mathrm{OH} 43210$, USA \\ ${ }^{\mathrm{f}}$ Atmospheric Turbulence and Diffusion Division, NOAA/ARL, TN 37831-2456, USA \\ ${ }^{\mathrm{g}}$ School of Forest Resources and Conservation, University of Florida, Gainesville, FL 32611-0410, USA \\ h Biosciences Division, Argonne National Laboratory, IL 60439, USA \\ ${ }^{\mathrm{i}}$ Department of Biology, Indiana University, IN 47405, USA \\ ${ }^{\mathrm{j}}$ Department of Geography, Indiana University, IN 47405, USA \\ ${ }^{\mathrm{k}}$ Department of Geography, The George Washington University, Washington DC 20052, USA \\ ${ }^{1}$ Environmental Sciences Department, University of Virginia, Charlottesville, VA 22904-4123, USA
}

\section{A R T I C L E I N F O}

\section{Article history:}

Received 11 March 2014

Received in revised form 30 October 2014

Accepted 3 November 2014

Available online 26 November 2014

\section{Keywords:}

Gross primary production

Eddy covariance

Carbon flux model

Light use efficiency

MODIS

\begin{abstract}
A B S T R A C T
Accurate simulation of terrestrial gross primary production (GPP), the largest global carbon flux, benefits our understanding of carbon cycle and its source of variation. This paper presents a novel light use efficiency-based GPP model called the terrestrial ecosystem carbon flux model (TEC) driven by MODIS FPAR and climate data coupled with a precipitation-driven evapotranspiration $(E)$ model (Yan et al., 2012). TEC incorporated a new water stress factor, defined as the ratio of actual $E$ to Priestley and Taylor (1972) potential evaporation ( $\left.E_{\mathrm{PT}}\right)$. A maximum light use efficiency $\left(\varepsilon^{*}\right)$ of $1.8 \mathrm{gC} \mathrm{MJ}^{-1}$ and $2.76 \mathrm{gC} \mathrm{MJ}^{-1}$ was applied to C3 and C4 ecosystems, respectively. An evaluation at 18 eddy covariance flux towers representing various ecosystem types under various climates indicates that the TEC model predicted monthly average GPP for all sites with overall statistics of $r=0.85, \mathrm{RMSE}=2.20 \mathrm{gC} \mathrm{m}^{-2} \mathrm{day}^{-1}$, and bias $=-0.05 \mathrm{gC} \mathrm{m}^{-2} \mathrm{day}^{-1}$. For comparison the MODIS GPP products (MOD17A2) had overall statistics of $r=0.73$, RMSE $=2.82 \mathrm{gC} \mathrm{m}^{-2} \mathrm{day}^{-1}$, and bias $=-0.31 \mathrm{gC} \mathrm{m}^{-2} \mathrm{day}^{-1}$ for this same set of data. In this case, the TEC model performed better than MOD17A2 products, especially for C4 plants. We obtained an estimate of global mean annual GPP flux at $128.2 \pm 1.5 \mathrm{PgC} \mathrm{Cr}^{-1}$ from monthly MODIS FPAR and European Centre for Medium-Range Weather Forecasts (ECMWF) ERA reanalysis data at a $1.0^{\circ}$ spatial resolution over 11 year period from 2000 to 2010. This falls in the range of published land GPP estimates that consider the effect of C4 and C3 species. The TEC model with its new definition of water stress factor and its parameterization of C4 and C3 plants should help better understand the coupled climate-carbon cycle processes.
\end{abstract}

() 2014 Elsevier B.V. All rights reserved.

\footnotetext{
* Corresponding author at: National Meteorological Center, China Meteorological Administration, Beijing 100081, China. Tel.: +86 1058995040.

E-mail addresses: yanhaon@hotmail.com (H. Yan), sqwang@igsnrr.ac.cn (S.-q. Wang), dbillesbach1@unl.edu (D. Billesbach), oechel@sunstroke.sdsu.edu (W. Oechel), bohrer.17@osu.edu (G. Bohrer), tilden.meyers@noaa.gov (T. Meyers), tamartin@ufl.edu (T.A. Martin), matamala@anl.gov (R. Matamala), rpp6@indiana.edu (R.P. Phillips), farahman@indiana.edu (F. Rahman), qy4a@virginia.edu (Q. Yu), hhs@virginia.edu (H.H. Shugart).
}

\section{Introduction}

In the past decades (1980s and 1990s), the Earth experienced dramatic environment changes. It had the warmest decades in the instrumental record and a significant increase in atmospheric $\mathrm{CO}_{2}$ levels (Houghton et al., 2001; Hansen et al., 2007). Terrestrial ecosystems, including both vegetation and soil carbon pools, play an important role in the carbon cycle between land and 
atmosphere through photosynthesis and respiration. Gross primary production (GPP) is a measure of gross primary photosynthesis. Autotrophic respiration consumes about half of GPP (Chapin et al., 2002); the remainder is the net primary production (NPP). Accurate estimation of terrestrial ecosystem production at various temporal scales will improve our understanding of global carbon cycle and its relationship with climate change and atmospheric $\mathrm{CO}_{2}$ change. For example, analysis of satellite-based NPP reveals that recent climatic changes have enhanced plant growth in northern mid-latitudes and high latitudes from 1982 to 1999 (Nemani et al., 2003). Improving operational light use efficiency (LUE) algorithms for monitoring global GPP and NPP benefits the study of trends in the global carbon budget (Huntzinger et al., 2012; Turner et al., 2003).

For this reason, efforts have been made to improve estimated GPP and NPP by using both statistical models and process models. Several statistical models such as the simple temperature and greenness model (TG model; Sims et al., 2008), the regression tree approach (Xiao et al., 2010), the support vector machine model (SVM; Yang et al., 2007), model tree ensembles (MTE; Jung et al., 2011), remote sensing based greenness and radiation model (GR; Wu et al., 2011), the total canopy chlorophyll content and potential incident photosynthetically active radiation model (Gitelson et al., 2012), the temperature and greenness rectangle model (TGR; Yang et al., 2013), and the photosynthetic capacity model (PCM; Gao et al., 2014) have been developed to estimate GPP. Calibrations are required to build statistical GPP models. Conversely, training data determine the accuracy of GPP models. Another feature of statistical GPP models is that while they match the particular climate or vegetation types characterizing the training data, they may need re-calibration when extended to other climates or vegetation types. Recently, Yang et al. (2014) presented a simple model to estimate GPP in nonforest ecosystems by inverting the MODIS evapotranspiration (E) product (MOD16) using ecosystem water use efficiency $($ WUE $=\mathrm{GPP} / E)$.

Process models require detailed parameterization of vegetation, as well as soil and atmosphere, to simulate the vegetation's physiology (e.g., photosynthesis, autotrophic respiration, and transpiration). Since satellites can supply large-scale observation of terrestrial vegetation, a diverse set of satellite-based process models have developed quickly during recent years. These have the potential to accurately predict GPP and NPP from regional to continental scales (Potter et al., 1993; Ruimy et al., 1994; Field et al., 1995; Running et al., 2000; Xiao et al., 2005a; Yuan et al., 2007; Yang et al., 2007). Remote sensing-based process models are principally based on the light-use-efficiency theory - photosynthesis production correlates with the absorbed photosynthetically active radiation (APAR) (Monteith, 1972; Asrar et al., 1984) and FPAR is derived from remote sensing data,

$\mathrm{GPP}=\varepsilon \times \mathrm{APAR}=\varepsilon * \times S_{\text {stress }} \times \mathrm{FPAR} \times \mathrm{PAR}$

where GPP is the gross primary production $\left(\mathrm{gC} \mathrm{m}^{-2}\right.$ month $\left.^{-1}\right), \varepsilon$ is the actual LUE $\left(\mathrm{gC} \mathrm{MJ}^{-1}\right)$ including environmental stresses and is often defined as $\varepsilon^{*} \times S_{\text {stress, }}, \varepsilon^{*}$ is the maximum LUE and $S_{\text {stress }}$ refers to environmental stresses, FPAR is the fraction of PAR absorbed by the canopy, and PAR is the incident photosynthetically active radiation $\left(\mathrm{MJ} \mathrm{m}^{-2}\right.$ month $\left.^{-1}\right)$. The fraction of PAR in the incident global radiation $\mathrm{Q}\left(\mathrm{MJ} \mathrm{m} \mathrm{month}^{-1}\right)$ is assumed to be 0.48 (McCree, 1972). Because of remote sensing data adopted as model inputs, they are sometimes called 'diagnostic models' (Ruimy et al., 1996; King et al., 2011).

Most LUE models attempt to couple the effects of temperature and water (e.g., soil moisture (SM), vapor pressure deficit $(D)$, canopy water content) on the maximum light-use-efficiency which is either a universal constant for different ecosystems (Potter et al., 1993; Yuan et al., 2007), or changes in different ecosystem (Running et al., 2000).

As a key variable in LUE models, estimation of $\varepsilon$ has attracted multiple studies resulting in different parameterizations (Table 1 ). TURC GPP model simply defines $\varepsilon$ as a constant of $1.21 \mathrm{~g} \mathrm{CMJ}^{-1}$ (Ruimy et al., 1996). C-Fix GPP model sets $\varepsilon-\varepsilon^{*}$ multiplied by a simple function of temperature $\left(T_{\varepsilon}\right)$ and, as a partial water-limitedmodel, assumes NDVI-derived FPAR depending on plant water availability at month scale (Veroustraete et al., 2002; Verstraeten et al., 2006).

As SM and $D$ directly affect photosynthesis, recent GPP models explicitly consider the effect of moisture in addition to temperature. However, the effect of water stress on ecosystem photosynthesis is probably the most uncertain factor in current LUE GPP models (Grant et al., 2006) and numerous definitions of waterstress factor (i.e., SM, D, evaporative fraction (EF), and satellitederived land surface water index) have been applied (Table 1).

Table 1

The definition of light use efficiency $\varepsilon$, water stress factor $W_{\varepsilon}$, and maximum light use efficiency $\varepsilon^{*}$ in twelve remote sensing-based GPP or NPP models.

\begin{tabular}{|c|c|c|c|c|}
\hline Model & $\varepsilon\left(\mathrm{gCMJ}^{-1}\right)^{\mathrm{a}}$ & $W_{\varepsilon}$ & $\varepsilon^{*}\left(\mathrm{gC} \mathrm{MJ}^{-1}\right)$ & Citation \\
\hline TURC & $\varepsilon_{\mathrm{g}}=\varepsilon^{*}$ & No & 1.21 & Ruimy et al. (1996) \\
\hline C-Fix & $\varepsilon_{\mathrm{g}}=\varepsilon^{*} \times T_{\varepsilon}$ & No & 1.1 for forest & Veroustraete et al. (2002) \\
\hline MOD17 & $\varepsilon_{\mathrm{g}}=\varepsilon^{*} \times T_{\varepsilon} \times W_{\varepsilon}$ & $W_{\varepsilon}=\frac{D_{\max }-D}{D_{\max }-D_{\min }}$ & $0.604-1.259$ & Running et al. (2000) \\
\hline VPM & $\varepsilon_{\mathrm{g}}=\varepsilon^{*} \times T_{\varepsilon} \times W_{\varepsilon}$ & $W_{\varepsilon}=\frac{(1+\mathrm{LSWI})}{\left(1+\mathrm{LSWI}_{\max }\right)}$ & $2.208,2.484$ for forest & Xiao et al. (2005a,b) \\
\hline BEAMS & $\varepsilon_{\mathrm{g}}=\varepsilon^{*} \times P_{\text {actual }} \times P_{\max }$ & $W_{\varepsilon}=P_{\text {actual }} / P_{\max }$ & $0 \sim 1$ & Sasai et al. (2007) \\
\hline $\begin{array}{l}\text { GLO-PEM } \\
\text { TOPS }\end{array}$ & $\begin{array}{l}\varepsilon_{\mathrm{g}}=\varepsilon^{*} \times T_{\varepsilon} \times W_{\varepsilon} \\
\varepsilon_{\mathrm{g}}=\varepsilon^{*} \times \min \left(T_{\varepsilon}, W_{\varepsilon}\right)\end{array}$ & $W_{\varepsilon}=\min (f(\mathrm{SM}), f(D))$ & $\begin{array}{l}55.2 \alpha \text { for } \mathrm{C} 3 ; 2.76 \text { for } \mathrm{C} 4 \\
\text { Variable }\end{array}$ & $\begin{array}{l}\text { Prince and Goward (1995) } \\
\text { Nemani et al. (2009) }\end{array}$ \\
\hline 3-PG & $\varepsilon_{\mathrm{g}}=\varepsilon^{*} \times T_{\varepsilon} \times W_{\varepsilon} \times S_{\mathrm{a}}$ & $W_{\varepsilon}=\min (f(\mathrm{SM}), f(D))$ & 1.8 & Landsberg and Waring (1997) \\
\hline CFLUX & $\varepsilon_{\mathrm{g}}=\varepsilon^{*} \times T_{\varepsilon} \times W_{\varepsilon} \times S_{\mathrm{a}}$ & $W_{\varepsilon}=\min (f(\mathrm{SM}), f(D))$ & $0.9 \sim 4.0$ & King et al. (2011) \\
\hline CASA & $\varepsilon_{\mathrm{n}}=\varepsilon^{*} \times T_{\varepsilon 1} \times T_{\varepsilon 2} \times W_{\varepsilon}$ & $W_{\varepsilon}=0.5+0.5 E / E_{\mathrm{Th}}$ & 0.39 & Potter et al. (1993) \\
\hline EC-LUE & $\varepsilon_{\mathrm{g}}=\varepsilon^{*} \times \min \left(T_{\varepsilon}, W_{\varepsilon}\right)$ & $W_{\varepsilon}=E / R_{\mathrm{n}}$ & 2.14 & Yuan et al. (2007) \\
\hline TEC & $\varepsilon_{\mathrm{g}}=\varepsilon^{*} \times T_{\varepsilon} \times W_{\varepsilon}$ & $W_{\varepsilon}=E / E_{\mathrm{PT}}$ & 1.8 for $\mathrm{C} 3 ; 2.76$ for $\mathrm{C} 4$ & This study \\
\hline
\end{tabular}

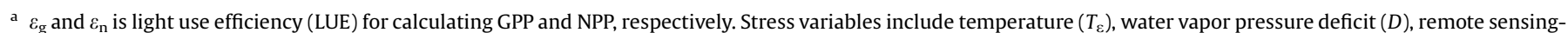


evaporation $\left(E_{\mathrm{Th}}\right)$, net radiation $\left(R_{\mathrm{n}}\right)$, Priestley and Taylor (1972) potential evaporation $\left(E_{\mathrm{PT}}\right)$.
} 
The MODIS-photosynthesis (PSN) model(MOD17) simply utilizes $D$ to depict the effect of water stress on stomatal conductance because stomatal conductance decreases with an increase of $D$ for many plant species (Jarvis, 1976) and further adopts variable $\varepsilon^{*}$ for each biome type (Running et al., 2000). The satellite-based vegetation photosynthesis (VPM) model uses a satellite-derived water index, i.e., land surface water index (LSWI), to represent leaf and canopy water content which is largely determined by dynamic changes of both SM and $D$ (Xiao et al., 2005a). Biosphere model integrating eco-physiological and mechanistic approaches using satellite data (BEAMS) GPP model defines the stress as a ratio of actual to maximum photosynthesis rate $\left(P_{\text {actual }}\right.$ and $\left.P_{\max }\right)$ calculated from a stomatal conductance-based leaf-photosynthesis model (Farquhar et al.,1980), which accounts for the biochemical control of temperature, relative humidity, and soil water content (Sasai et al., 2007). As SM and $D$ play independent water stress effect on photosynthesis and stomatal conductance under an assumption of no synergistic interaction (Jarvis, 1976), thus CFLUX (King et al., 2011), global production efficiency model (GLO-PEM; Prince and Goward, 1995), terrestrial observation and prediction system (TOPS; Nemani et al., 2009), and physiological principles predicting growth (3-PG; Landsberg and Waring, 1997) GPP models acquire respective definition of SM and $D$ (Table 1 ).

Another methodology to define water stress effects is based on the concept of evaporation ratio, which represents water stress effect on actual evapotranspiration $(E)$ and then GPP and NPP because $E$ and photosynthesis processes are tightly coupled (Potter et al., 1993; Yuan et al., 2007). However, different definitions of evaporation ratio are adopted in Carnegie-AmesStanford approach (CASA) NPP model and eddy covariance-light use efficiency (EC-LUE) GPP model; CASA NPP model defines evaporation ratio as a ratio of $E$ to Thornthwaite (1948) temperature-based potential evaporation $E_{\mathrm{Th}}$ (Potter et al., 1993) while EC-LUE GPP model uses EF, defined as $E$ divided by available energy, to indicate the impact of moisture stress on photosynthesis because decreasing amounts of energy partitioned in latent heat flux suggests a strong moisture stress (Yuan et al., 2007). However, Priestley and Taylor (1972) potential evaporation $\left(E_{\mathrm{PT}}\right)$, calculated from temperature and available energy, represents the potential evaporation over wet surface, thus in our opinion a new definition of water stress factor (i.e., the ratio of $E$ to $E_{\mathrm{PT}}$ ) might be expected to perform better in indicating the effects of moisture stress. To our knowledge, $E / E_{\mathrm{PT}}$ ratio-based water stress factor has never been adopted in previous satellite GPP and NPP models.

In summary, there are two categories of definitions of water stress factor $W_{\varepsilon}$ (i.e., $E / E_{\mathrm{PT}}$ (or $\mathrm{EF}$ ) and $f(\mathrm{SM}) \times f(D)$ ) (or minimum of $f(\mathrm{SM})$ and $f(D)$ ) in current GPP models as shown in Table 1 . The question is whether or not they play a similar role in showing the moisture stress on GPP estimation, a topic seldom addressed in previous studies of GPP models. A detailed summary of the definition of $\varepsilon, W_{\varepsilon}$, and $\varepsilon^{*}$ in twelve remote sensing-based GPP or NPP models can be found in Table 1 .

As eddy covariance flux towers can simultaneously observe carbon, water, and energy fluxes of terrestrial ecosystem and provide near real time and long-term information of ecosystem (Turner et al., 2003), they improve our understanding of carbon and water cycles in the boundary layer (Baldocchi et al., 2001; Baldocchi, 2003). Further analysis of flux data illustrates environmental controls over carbon dioxide and water vapor exchange of terrestrial vegetation (Law et al., 2002). Thus, more flux data measured at different ecosystem types have been used for calibration and evaluation of global LUE GPP models (Wang et al., 2004; Xiao et al., 2005a; Heinsch et al., 2006; Yuan et al., 2007; Yang et al., 2007; Sjöström et al., 2013).

Our intention in paper is to present a new remote sensing GPP model, the TEC model, which ingests MODIS LAI/FPAR, relative humidity, air temperature, and incident global radiation, precipitation, net radiation as model variables. The following sections will present: (1) development of the TEC GPP model, especially the water stress factor derived from actual $E$ divided by $E_{\mathrm{PT}}$; (2) evaluation of the TEC GPP model at 18 independent flux tower sites representing different ecosystems; (3) detailed comparison with MOD17A2 GPP products; (4) comparison of two kinds of water stress factors, e.g., $E / E_{\mathrm{PT}}$ and $f(\mathrm{SM}) \times f(D)$; (5) discussion and the application of the TEC model for GPP estimation on a large scale.

\section{Datasets and pre-processing}

\subsection{Flux evaluation data}

Monthly averaged flux tower data and MODIS 8-day MOD15 LAI/FPAR and MOD17 GPP products available at Oak Ridge National Laboratory' Distributed Active Archive Center (ORNL DAAC) web site (http://public.ornl.gov/ameriflux/data-access. shtml) were employed in this paper.

\subsubsection{Eddy covariance data}

As soil data, including soil depth and soil texture, are used to calculate soil water characteristics so as to estimate actual $E$ based on Air-Relative-humidity-based Two-Source (ARTS) E model (Yan et al., 2012), only 18 flux sites with available soil data were selected from Ameriflux flux tower sites and measured GPP, E, and meteorological data by the eddy covariance (EC) method were used in this study. The EC method is regarded as the best method to directly measure fluxes (Paw et al., 2000) and has been widely applied to global $\mathrm{CO}_{2}$, water, energy measurements at flux tower sites in FLUXNET (Baldocchi et al., 2001). The AmeriFlux network, which was established in 1996, provides continuous observations of ecosystem level exchanges of $\mathrm{CO}_{2}$, water, energy and momentum spanning diurnal, synoptic, seasonal, and interannual time scales from micro-meteorological tower sites.

The monthly averaged level 4 eddy covariance data (GPP, latent heat flux $\lambda E$, air temperature $T_{\mathrm{a}}$, precipitation $P_{\mathrm{r}}$, vapor pressure deficit $D$, and global radiation) and the half-hourly level-3 data (relative humidity $\mathrm{RH}$, net radiation $R_{\mathrm{n}}$, and wind speed $u$ ) used in this study were downloaded from the AmeriFlux network (ftp:// cdiac.ornl.gov/pub/ameriflux/data). The half-hourly data were further processed to the monthly averaged data to match the other eddy covariance data.

The TEC GPP algorithm was verified at 18 independent Ameriflux tower sites (Table 2) covering a range of different ecosystem types: deciduous broadleaf forest, mixed forest, evergreen needleleaf forest, crop, grasslands, chaparral, and savanna. These sites were grouped into three major classes (Table 2) so that each class had ample validation dataset: forest lands (evergreen forest, deciduous forest, mixed forest), crop lands (maize, wheat, soybean), and grasslands (grassland, tundra, chaparral and savanna). Six sites (i.e., Bondville, FermiA, MeadI, MeadIR, MeadR, and FermiP) are dominated by C4 plants; the other twelve sites are covered by C3 plants. Detailed descriptions of flux sites can be found at the website of http://public.ornl.gov/ ameriflux/site-select.cfm.

\subsubsection{MODIS LAI/FPAR products (MOD15A2)}

MODIS is the primary instrument onboard the National Aeronautics and Space Administration (NASA), Earth Observing System (EOS) sunsynchronous Terra satellite (10:30 am descending node) and Aqua satellites (1:30 pm ascending node) with 36 spectral bands ranging in wavelength from $0.4 \mu \mathrm{m}$ to $14.4 \mu \mathrm{m}$. The spatial resolution of band $1-2$ is $250 \mathrm{~m}$ at nadir, $500 \mathrm{~m}$ for bands $3-7$, and $1 \mathrm{~km}$ for the remaining 29 bands (Kaufman et al., 1998; Barnes et al., 1998). 
Table 2

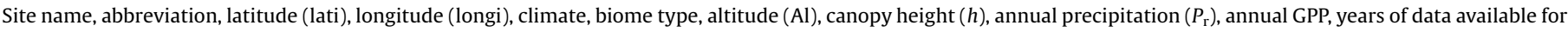
each flux site in this study, and citation.

\begin{tabular}{|c|c|c|c|c|c|c|c|c|c|c|}
\hline Site name & Abbreviation & Lati/longi & Climate & Biome $^{a}$ & $\begin{array}{l}\mathrm{Al} \\
(\mathrm{m})\end{array}$ & $h(\mathrm{~m})$ & $\begin{array}{l}\operatorname{Pr} \\
(\mathrm{mm})\end{array}$ & $\begin{array}{l}\text { GPP } \\
\left(\mathrm{gC} \mathrm{m}^{-2}\right)\end{array}$ & Years & Citation \\
\hline Bartlett experimental forest & Bartlett & $44.06 /-71.29$ & Temperate & DBF & 272 & 19 & 1300 & 1084 & $\begin{array}{l}2004- \\
2005\end{array}$ & Desai et al. (2008) \\
\hline Metolius intermediate pine & MetoliusI & $44.50 /-121.62$ & Temperate & ENF & 1253 & 14 & 728 & 1341 & $\begin{array}{l}2005- \\
2007\end{array}$ & Thomas et al. (2009) \\
\hline Metolius new young pine & MetoliusN & $44.32 /-121.61$ & Temperate & ENF & 1008 & 3.11 & 472 & 838 & $\begin{array}{l}2004- \\
2005\end{array}$ & Irvine et al. (2007) \\
\hline Mize & Mize & $29.76 /-82.24$ & Subtropical & ENF & 43 & 10.1 & 1228 & 2095 & $\begin{array}{l}2001- \\
2004\end{array}$ & Clark et al. (2004) \\
\hline Morgan Monroe state forest & Morgan & $39.32 /-86.41$ & Temperate & $\mathrm{DBF}$ & 275 & 27 & 1094 & 1544 & $\begin{array}{l}2001- \\
2003\end{array}$ & Dragoni et al. (2007) \\
\hline $\begin{array}{l}\text { University of Michigan biological } \\
\text { station }\end{array}$ & UMBS & $45.56 /-84.71$ & Temperate & DBF & 234 & 21 & 750 & 1134 & $\begin{array}{l}2001- \\
2003\end{array}$ & Nave et al. (2011) \\
\hline Wind river crane site & WindR & $45.82 /-121.95$ & Mediterranean & ENF & 371 & 56.3 & 2223 & 1611 & $\begin{array}{l}2001- \\
2002\end{array}$ & Falk et al. (2008) \\
\hline ARM SGP main & SGP & $36.61 /-97.49$ & Temperate & Crop & 314 & 0.5 & 901 & 574 & $\begin{array}{l}2003- \\
2005\end{array}$ & Sheridan et al. (2001) \\
\hline Bondville & Bondville & $40.01 /-88.29$ & Temperate & Crop & 219 & 3 & 990 & 1186 & $\begin{array}{l}2001- \\
2004\end{array}$ & Chen et al. (2008) \\
\hline Fermi agricultural & FermiA & $41.86 /-88.22$ & & Crop & 225 & 2 & 921 & 921 & $\begin{array}{l}2005- \\
2007\end{array}$ & Xiao et al. (2008) \\
\hline Mead irrigated & MeadI & $41.16 /-96.47$ & Temperate & Crop & 361 & 2.9 & 887 & 1457 & $\begin{array}{l}2002- \\
2005\end{array}$ & $\begin{array}{l}\text { Suyker and Verma } \\
(2008)\end{array}$ \\
\hline Mead irrigated rotation & MeadIR & $41.16 /-96.47$ & Temperate & Crop & 362 & 1.83 & 887 & 1169 & $\begin{array}{l}2002- \\
2005\end{array}$ & Grant et al. (2007) \\
\hline Mead rainfed & MeadR & $41.17 \mid-96.43$ & Temperate & Crop & 363 & 1.71 & 887 & 1064 & $\begin{array}{l}2002- \\
2005\end{array}$ & Grant et al. (2007) \\
\hline Fermi prairie & FermiP & $41.84 /-88.24$ & & Grass & 226 & 1 & 921 & 1222 & $\begin{array}{l}2005- \\
2006\end{array}$ & Xiao et al. (2008) \\
\hline Barrow & Barrow & $71.32 /-156.63$ & Tundra & Grass & 1 & 0.25 & 1140 & 1050 & $\begin{array}{l}2004- \\
2005\end{array}$ & Harazono et al. (2003) \\
\hline Santa Rita mesquite savanna & Santa & $31.82 /-110.87$ & Subtropical & Shrub & 1116 & 2.5 & 310 & 241 & $\begin{array}{l}2004- \\
2006\end{array}$ & Scott et al. (2009) \\
\hline Tonzi ranch & Tonzi & $38.43 /-120.97$ & Mediterranean & Savanna & 177 & 9.41 & 558 & 843 & $\begin{array}{l}2003- \\
2005\end{array}$ & Ma et al. (2007) \\
\hline Vaira ranch & Vaira & $38.41 /-120.95$ & Mediterranean & Savanna & 129 & 0.55 & 565 & 689 & $\begin{array}{l}2001- \\
2005\end{array}$ & Ryu et al. (2008) \\
\hline
\end{tabular}

a Deciduous broadleaf forest (DBF), Evergreen needleleaf forest (ENF)

The MODIS LAI/FPAR products are retrieved from MODIS surface reflectances at up to 7 spectral bands by using a threedimensional formulation of the radiative transfer process in vegetation canopies (Knyazikhin et al., 1998; Myneni et al., 2002). However, a back-up algorithm estimates LAI and FPAR with empirical MODIS specific NDVI-LAI and NDVI-FPAR relationships when the main algorithm fails due to clouds or atmosphere effects (Yang et al., 2006). The products were originally generated daily at $1 \mathrm{~km}$ spatial resolution and an 8-day compositing procedure was developed to provide high quality cloudless data in MODIS land products. Note that MODIS geolocation product (MOD03) has its own uncertainty, which could be up to several hundred meters, thus MODIS LAI product is affected because it requires at least 3 by 3 pixel averages to incorporate stochastic random variable in calculating LAI (Tan et al., 2006).

MOD15A2 collection 5 (C5) LAI/FPAR products, used for driving the TEC model at flux sites in this study, were downloaded from the ORNL DAAC (ftp://daac.ornl.gov/data/modis_ascii_subsets/) in a form of ASCII subset data covering a $7 \times 7 \mathrm{~km}^{2}$ area centered on each flux tower. Single pixels containing the coordinates for a flux tower were extracted from LAI/FPAR products for calculating $E$ and GPP. Its companion quality control (QC) data were used to check the quality of the MODIS LAI/FPAR data. All good quality data with MODLAND_QC $=0$ (main algorithm) or SCF_QC $=2$ or 3 (empirical back-up algorithm) were kept, while all other poor quality data were deleted and replaced by linear interpolation from the nearest reliable data as suggested by Zhao et al. (2005). MOD15A2C5 LAI/ FPAR products refine the obvious overestimation of LAI in old collection 4 (C4) LAI products (Yang et al., 2006). In the TEC algorithm, MODIS FPAR was directly applied to estimating GPP while MODIS LAI was only related to actual $E$ retrieval by using ARTS E model (Yan et al., 2012).

\subsubsection{MODIS GPP product (MOD17A2)}

The operational MOD17A2 GPP/NPP global products at $1 \mathrm{~km}$ spatial resolution and 8-day temporal resolution are calculated from NASA's Global Modeling and Assimilation Office (GMAO) meteorological reanalysis data, biome type-specific maximum conversion efficiency, and MOD15A2 FPAR product according to the LUE concept (Zhao et al., 2005; Heinsch et al., 2006). The MOD17A2 collection 5 (C51) 8-day GPP/NPP products improve the spatial interpolation of the coarse resolution GMAO meteorological data and cloud-contaminated MOD15A2 FPAR data found in previous collection $4 \mathrm{GPP} / \mathrm{NPP}$ products (Zhao et al., 2005). The MOD17A2C51 GPP products, used for evaluating the TEC GPP model at flux sites in this study, were downloaded from ORNL DAAC (ftp://daac.ornl.gov/data/modis_ascii_subsets/) in a form of ASCII subset data.

The MODIS GPP algorithm (Running et al., 2000, 2004) is based on the Monteith LUE theory (1972) and the MOD17 GPP is calculated as:

$\mathrm{GPP}=\varepsilon_{\max } \times m\left(T_{\min }\right) \times m(D) \times \mathrm{FPAR} \times \mathrm{PAR}$

where $\varepsilon_{\max }$ is the biome-specific maximum conversion efficiency, $m\left(T_{\min }\right)$ as a scalar reduces $\varepsilon_{\max }$ when cold temperature $T_{\min }$ limits plant growth, and $m(D)$ is another scalar used to reduce $\varepsilon_{\max }$ when 
vapor pressure deficit $D$ is high enough to inhibit photosynthesis, PAR is the incident photosynthetically active radiation, and FPAR is the fraction of PAR absorbed by the canopy. $D$ equals the saturated vapor pressure $e_{\mathrm{s}}$ minus the actual vapor pressure $e_{\mathrm{a}}$. The scalar of $m(D)$ is defined as,

$m(D)=\left\{\begin{array}{lc}1 & D \leq D_{\text {open }} \\ \frac{D_{\text {close }}-D}{D_{\text {close }}-D_{\text {open }}} & D_{\text {open }}<D<D_{\text {close }} \\ 0.1 & D \geq D_{\text {close }}\end{array}\right.$

where 'close' indicates total inhibition and 'open' indicates no inhibition. The scalar of $m(D)$ changes from 0.1 (nearly total inhibition) to 1 (no inhibition). Biome-specific values of $D_{\text {close }}$ and $D_{\text {open }}$ for a range of biomes and the biome-specific maximum conversion efficiency are listed in a biome properties look-up table (BPLUT) (Running et al., 2000, 2004). The GPP algorithm does not include the effect of soil water stress, and sensitivity of GPP to $D$ is increased in the MOD17 GPP model to partially account for the problem (Heinsch et al., 2006).

Although MOD17A2 GPP is the only global-scale operational GPP product in high temporal and spatial resolutions, recent validation studies (Turner et al., 2003; Rahman et al., 2005; Yang et al., 2007) show that it has considerable errors due to problems associated with: inputs of climate data (Turner et al., 2006; Zhao et al., 2005); use of biome properties look-up table (Heinsch et al., 2006; Turner et al., 2006); the MOD17 algorithm itself(Heinsch et al., 2006).

\subsection{Global data}

MOD15A2 collection 5 (C5) global $1 \mathrm{~km}$ spatial resolution, 8-day composite green LAI/FPAR products, used for global TEC GPP estimation in this study, were downloaded from the Land Processes Distributed Active Archive Center (LP DAAC, ftp://e4ftl01.cr.usgs.gov/MOLT/). All other poor quality data of LAI/FPAR products were deleted and data gaps were filled using linear temporal interpolation. This method successfully fills data gaps even in tropical regions, often covered by cloud, as shown by Zhao et al. (2005). Further, 8-day FPAR data was averaged to monthly temporal and finally used for driving TEC GPP model in this study.

MOD17A3 global yearly GPP products were directly used to evaluate the TEC GPP model spanning 2000-2010 in this study. The new version-55 of the Terra MODIS GPP/NPP products was produced by the Numerical Terradynamic Simulation Group (NTSG)/University of Montana (UMT). It corrected the problem with cloud-contaminated MODIS LAI/FPAR inputs to the MOD17 algorithm (Zhao et al., 2005).

The input European Centre for Medium-Range Weather Forecasts (ECMWF) ERA-Interim reanalysis data was applied to driving TEC GPP model and its coupled ARTS E model. ERA-Interim data, as the latest global atmospheric reanalysis covering the period of 1979-2012, has been produced by ECMWF with substantial improvements in the representation of the hydrological cycle, the quality of the stratospheric circulation, and the consistency in time of the reanalyzed fields (Dee et al., 2011). Its assimilating model features T255 horizontal resolution, 60 vertical levels extending from the surface up to $0.1 \mathrm{hPa}$, and 12-hourly four-dimensional variational analysis (4D-Var) that includes the adaptive estimation of biases in satellite radiance data (Dee et al., 2011).

ERA PAR at the surface, surface net solar radiation, surface net thermal radiation, $10 \mathrm{~m}$ wind speed, $2 \mathrm{~m}$ dewpoint temperature, and $2 \mathrm{~m}$ air temperature data at a resolution of $1.5^{\circ} \times 1.5^{\circ}$ were downloaded from ECMWF (http://data-portal.ecmwf.int/).
C3 and C4 plants are two fundamental plant functional types (PFTs) with different responses to light, temperature, $\mathrm{CO}_{2}$, and nitrogen during the photosynthetic process with distinctive photosynthetic pathways (Pau et al., 2013). A fine-scale distribution of these plant types is required for modeling GPP. To apply different maximum light use efficiency $\varepsilon^{*}$ to $\mathrm{C} 3$ and $\mathrm{C} 4$ plants in modeling global land GPP, we used the global $1^{\circ}$ griddeddistribution of $\mathrm{C} 3$ and $\mathrm{C} 4$ plant percentage data that was derived from the C4 climate map, continuous fields/plant growth form dataset, crop fraction distribution, and crop type harvest area statistics (Still et al., 2003). Several scenarios were adopted to produce the $\mathrm{C} 4$ plant fraction in each grid cell to treat natural (i.e., climate, fire) and anthropogenic (i.e., crop) controls on the distribution of C4 and C3 plants. C4 and C3 plants occupy $18.8 \times 10^{6}$ and $87.4 \times 10^{6} \mathrm{~km}^{2}$, respectively, with remainder of the global land covered with ice and bare ground (Still et al., 2003). The C4 plant percentage data has been successfully used in estimating global land GPP (Still et al., 2003; Ryu et al., 2011).

The Global Precipitation Climatology Centre (GPCC) data is a $0.5^{\circ}$ latitude/longitude, gridded dataset of monthly terrestrial surface precipitation climate over the period 1901-2010. The GPCC project is operated by National Meteorological Service of Germany under the auspices of the World Meteorological Organization (WMO). A Full Data Reanalysis Product of precipitation, used in this study, was developed by using an empirical interpolation method SPHEREMAP (Willmott et al., 1985) from an available GPCC station database (67,200 stations with at least 10 years of data) complied from all available sources (Rudolf et al., 2011). Monthly GPCC timeseries show month-by-month variations in precipitation climate.

Global $1^{\circ}$ gridded surfaces of selected soil characteristics including maximum soil available water content (MAWC) for a soil depth of $0-150 \mathrm{~cm}$ developed by International Geosphere-Biosphere Programme (IGBP) - Data and Information Services (DIS) were downloaded from the ORNL DAAC (http://daac.ornl.gov/).

All global forcing data including MOD15A2 LAI/FPAR products, GPCC precipitation dataset, and ERA-Interim monthly reanalysis meteorological data were re-sampled to a $1.0^{\circ} \times 1.0^{\circ}$ grid resolution by using a bilinear interpolation method, and then applied to driving the TEC GPP model and its coupled ARTS E model on a monthly timescale.

\section{Development of global Terrestrial Ecosystem Carbon flux (TEC) GPP model}

The TEC model simulates GPP of terrestrial ecosystem from the general form of the LUE model (Eq. (1)) suggested by Monteith (1972). As the light use efficiency $\varepsilon$ actually varies with several environmental and vegetation-related parameters (Maisongrande et al., 1995; Ruimy et al., 1994), temperature and water stresses are taken into consideration in TEC-GPP model,

$\varepsilon=\varepsilon * \times T_{\varepsilon} \times W_{\varepsilon}$

$\mathrm{GPP}=\varepsilon * \times T_{\varepsilon} \times W_{\varepsilon} \times \mathrm{FPAR} \times \mathrm{PAR}$

where $\varepsilon^{*}$ is the maximum light use efficiency, PAR is the incident photosynthetically active radiation $\left(\mathrm{MJ} \mathrm{m} \mathrm{month}^{-1}\right)$, and $T_{\varepsilon}$ and $W_{\varepsilon}$ account for effects of temperature stress and water stress on light use efficiency of ecosystem, respectively. TEC uses a universal $\varepsilon^{*}$ with a value of $1.8 \mathrm{gC} \mathrm{MJ}^{-1}$ observed for C3 species in field (Waring et al., 1995) and already employed by 3-PG model (Landsberg and Waring, 1997). However, as leaf photosynthetic rates of C4 species are greater than those of C3 species (Jones, 1992; Pearcy and Ehleringer, 1984; Prince and Goward, 1995; Baldocchi, 1994). Verma et al. (2005) also reported that the peak $\mathrm{CO}_{2}$ uptake 
for C4 maize is about two times of the value for C3 soybean and the annual GPP of soybean is only $45-55 \%$ of maize GPP with or without irrigation, thus to solve such GPP estimation error induced by C3 and C4 species, TEC uses a universal $\varepsilon^{*}=2.76 \mathrm{~g} \mathrm{C} \mathrm{MJ}^{-1}$ for C4 species as suggested by Prince and Goward (1995).

$T_{\varepsilon}$ is calculated using the temperature stress equation developed for the Terrestrial Ecosystem Model (Raich et al., 1991),

$T_{\varepsilon}=\frac{\left(T_{\mathrm{a}}-T_{\min }\right)\left(T_{\mathrm{a}}-T_{\max }\right)}{\left(T_{\mathrm{a}}-T_{\min }\right)\left(T_{\mathrm{a}}-T_{\max }\right)-\left(T_{\mathrm{a}}-T_{\mathrm{opt}}\right)^{2}}$

where $T_{\mathrm{a}}$ is the air temperature $\left({ }^{\circ} \mathrm{C}\right), T_{\min }, T_{\max }$, and $T_{\mathrm{opt}}$ are minimum, maximum, and optimal temperature for photosynthetic activities, respectively and the biome-dependent parameter values can be found in Melillo et al. (1993). The $T_{\varepsilon}$ equation shows that photosynthesis is suppressed at lower and higher thresholds of air temperature dependant on biome type. This $T_{\varepsilon}$ equation is also adopted by EC-LUE GPP model and VPM GPP model (Xiao et al., 2005a; Yuan et al., 2007).

The impact of water stress on leaf photosynthesis has been estimated as a function of $E / E_{\mathrm{P}}, \mathrm{EF}, \mathrm{SM}$ and/or $D$, and satellitederived water index in current GPP and NPP models (Yuan et al., 2007; Xiao et al., 2005a; Landsberg and Waring, 1997; Prince and Goward, 1995; Potter et al., 1993). As the E-based water stress factor provides a more direct measure of water stresses on vegetation photosynthesis than other water stress factors, thus $E$-based water stress factor is preferred to other forms of water stress factor. However, actual $E$ has to be normalized by different dividend such as available energy $A$ (Yuan et al., 2007) and $E_{\mathrm{Th}}$ (Potter et al., 1993) that is a function of monthly $T_{\mathrm{a}}$ (Thornthwaite, 1948). As $T_{\mathrm{a}}$ and $A$ are two key factors indicating heat resources for evaporation, thus $E_{\mathrm{PT}}$, due to including both contribution of $T_{\mathrm{a}}$ and $A$, is better as the dividend in calculating water stress factor compared with only $A$ or $T_{\mathrm{a}}$-based water stress factor.The water stress factor $W_{\varepsilon}$ in the TEC GPP model is defined as,

$W_{\varepsilon}=\frac{E}{E_{\mathrm{PT}}}$

where $E$ is actual evapotranspiration and $E_{\mathrm{PT}}$ is the Priestley and Taylor (1972) potential evaporation,

$E_{\mathrm{PT}}=\alpha \frac{\Delta A}{\Delta+\gamma}$

where $E_{\mathrm{PT}}$ is the potential evaporation $\left(\mathrm{W} \mathrm{m}^{-2}\right) ; A$ is the available energy $\left(\mathrm{W} \mathrm{m}^{-2}\right) ; \Delta$ is the gradient of the saturated vapor pressure to air temperature $\left(\mathrm{kPa}^{\circ} \mathrm{C}^{-1}\right) ; \gamma$ is the psychrometric constant $\left(\mathrm{kPa}^{\circ} \mathrm{C}^{-1}\right) . A$ is set to the net radiation $R_{\mathrm{n}}$ here, because soil heat flux $G$ can be ignored for daily and longer time steps in the calculation of $E$ (Allen, 1998). As $\alpha$ has a daily mean of $1.30 \pm 0.03$, $1.34 \pm 0.05$, and $1.33 \pm 0.21$ over saturated land surface at three sites respectively (Priestley and Taylor, 1972), TEC model uses an averaged mean of $\alpha=1.35$ to calculate $E_{\mathrm{PT}}$ over land surface.

The TEC GPP model calculates $E$ in Eq. (7) following the ARTS $E$ Model (Yan et al., 2012) that simulates the surface energy balance, soil water balance, and environmental constraints on $E$ with inputs of remotely sensed LAI $\left(L_{\mathrm{ai}}\right)$ and surface meteorological data. Initially, ARTS $E$ Model calculates the canopy transpiration $\left(E_{\mathrm{c}}\right)$ model (Monteith, 1965) coupled with a simple $L_{\mathrm{ai}}$-based canopy conductance $\left(G_{\mathrm{c}}\right)$ model, and the soil evaporation $\left(E_{\mathrm{s}}\right)$ equation modified from the air-RH-based model of evapotranspiration (ARM-ET) (Yan and Shugart, 2010) with an assumption of well-watered surface. Then a soil water balance model, with input of precipitation and maximum soil available water content, is adopted to scale total evapotranspiration $E_{0}$ (i.e., $E_{\mathrm{c}}$ plus $E_{\mathrm{s}}$ ) to actual $E$ in the ARTS $E$ model. It has been successfully applied to study the interannual variation of global land $E$ over 1982-2011 and the impact of El Niño Southern Oscillation (ENSO)
(Yan et al., 2013). A more detailed description of ARTS E model can be found in the reference (Yan et al., 2012, 2013).The TEC GPP model was evaluated on monthly scale by comparing its GPP against flux tower GPP products at 18 AmeriFlux sites. The standard statistical variables used in the evaluation are bias, root-mean-square-error (RMSE), and correlation coefficient $(r)$.

\section{Results}

\subsection{Evaluation of TEC GPP model at flux sites}

GPP measurements at 18 AmeriFlux sites representing various ecosystem types under various climates were used for validation of TEC GPP estimates. C3 and C4 crop rotations were incorporated into the TEC GPP model to give respective GPP estimates at several Ameriflux sites. The TEC model predicted monthly average GPP for all sites (samples $=672$ ) with overall statistics of $r=0.85$, RMSE $=$ $2.2 \mathrm{gC} \mathrm{m}^{-2} \mathrm{day}^{-1}$, and bias $=-0.05 \mathrm{gC} \mathrm{m}^{-2}$ day $^{-1}$ (Fig. $1 \mathrm{a}$ and Table 3). However, its performance varied for forest sites, crop sites, and grass sites. For the forest sites, TEC GPP (with an $r$ of 0.87 , a RMSE of $1.60 \mathrm{gC} \mathrm{m}^{-2} \mathrm{day}^{-1}$, and a bias of $0.04 \mathrm{gC} \mathrm{m}^{-2} \mathrm{day}^{-1}$ ) performed better than for crop sites and grass sites (RMSE of 2.67 and $2.05 \mathrm{gC} \mathrm{m}^{-2} \mathrm{day}^{-1}$, respectively).

The TEC GPP model can capture the seasonal variations and the magnitudes of GPP measurements at 18 sites (Fig. 2 and Table 3 ). The poorest correlations ( $r$ values ranging from 0.46 to 0.66 , Table 3 ) were found in a few sites such as SGP, Mize, and Vaira (Fig. 2). TEC GPP performance varied by flux site and ecosystem type (Table 3). For forest sites, RMSE had a lower value of $1.00 \mathrm{gC} \mathrm{m}^{-2} \mathrm{day}^{-1}$ at Bartlett and a higher value of $2.43 \mathrm{gC} \mathrm{m}^{-2}$ day $^{-1}$ at Mize. Forest $r$ values ranged from 0.66 at Mize to 0.97 at Bartlett. For crop sites, RMSE had a range of 1.52 at SGP to $3.64 \mathrm{gC} \mathrm{m}^{-2}$ day $^{-1}$ at MeadI. Crop $r$ values ranged from 0.46 at SGP to 0.94 at MeadR. For grass sites, RMSE had a range of $0.60 \mathrm{gC} \mathrm{m}^{-2} \mathrm{day}^{-1}$ at Santa to $3.91 \mathrm{gC} \mathrm{m}^{-2} \mathrm{day}^{-1}$ at Barrow $(r$ ranged from 0.64 at Vaira to 0.9 at Santa).

Evaluation at yearly scales for all data (Fig. 1b) showed that TEC GPP accuracy increased with temporal scale; the slope $k$ of linear regression also increased, from 0.73 for monthly TEC GPP to 1.06 for yearly TEC GPP. Yearly estimated TEC GPP (Fig. 1b) showed a better performance (RMSE $=0.77 \mathrm{gC} \mathrm{m}^{-2} \mathrm{day}^{-1}$, bias $=-0.1 \mathrm{gC} \mathrm{m}^{-2} \mathrm{day}^{-1}$, and $r=0.84$ ) compared with monthly TEC GPP.

\subsection{Evaluation of water stress factor of $\mathrm{E} \mathrm{E}_{P T}$ at site level}

As water stress factor plays a key role in GPP models, evaluation of water stress factor of estimated TEC $E / E_{\mathrm{PT}}$ against observed flux $E / E_{\mathrm{PT}}$ is essential. Fig. 3a shows that the TEC $E / E_{\mathrm{PT}}$ could explain $62 \%$ variation of flux $E / E_{\mathrm{PT}}$ across 18 flux sites with a RMSE of 0.18 and a bias of -0.01 . However, different seasonal variations of $E / E_{\mathrm{PT}}$ (Fig. 4a-c) were found at flux sites (e.g., Vaira, Bondville, and Mize) due to different $E$ and energy supply $E_{\mathrm{PT}}$ (Fig. $4 \mathrm{~d}-\mathrm{f}$ ).

Vaira site has an average precipitation of $565 \mathrm{~mm} \mathrm{yr}^{-1}$ featuring a Mediterranean climate with distinct dry and wet seasons, and growing season is confined to the wet season only, typically from October to early May. Dry season featured a higher $E_{\mathrm{PT}}$ but a lower actual $E$ (Fig. $4 \mathrm{~d}$ ). As a result, both TEC $E / E_{\mathrm{PT}}$ and flux $E / E_{\mathrm{PT}}$ had large seasonal variations showing a distinct transition from a wet season with a higher $E / E_{\mathrm{PT}}$ above 0.9 to a dry season with a lower $E / E_{\mathrm{PT}}$ below 0.1 (Fig. 4a), which indicates water supply controlled the variation of $E / E_{\mathrm{PT}}$ at Vaira (Fig. $4 \mathrm{~d}$ ) with a resulted higher $r$ of 0.93 between TEC $E / E_{\mathrm{PT}}$ vs. flux $E / E_{\mathrm{PT}}$ (Fig. $4 \mathrm{~h}$ ).

Bondville site has an annual rotation between corn (C4) and soybeans (C3) representing a temperate continental climate with an average precipitation of $990 \mathrm{~mm} \mathrm{yr}^{-1}$. As there was no obvious 

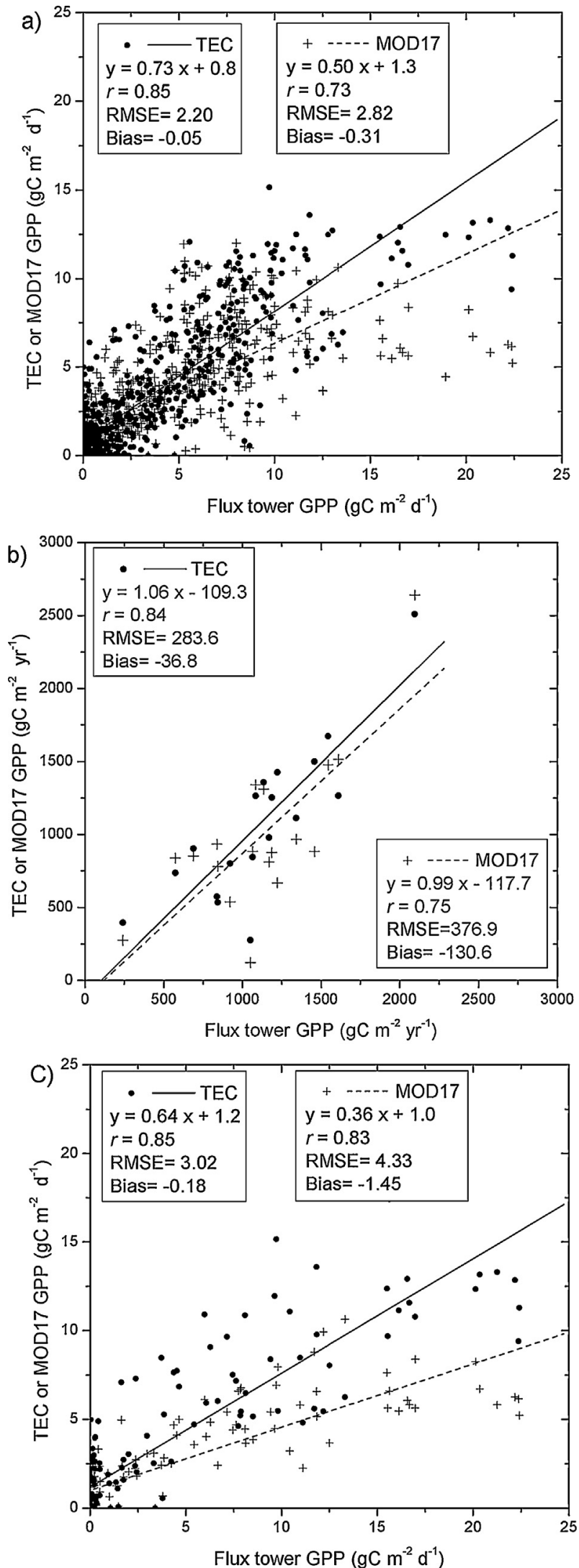

Fig. 1. Scatterplots of the observed flux tower GPP vs. estimated TEC GPP and MOD17 GPP for all data (a) on monthly scale and (b) on yearly scale, and (c) for C4 data at six sites on monthly scale.
Table 3

Site name and monthly statistics (bias $\left(\mathrm{gC} \mathrm{m}^{-2} \mathrm{day}^{-1}\right)$, RMSE $\left(\mathrm{gC} \mathrm{m}^{-2} \mathrm{day}^{-1}\right)$, and correlation coefficient $r$ ) for TEC GPP and MOD17A2 GPP estimation for the number $(N)$ of available MODIS FPAR data and flux datasets

\begin{tabular}{|c|c|c|c|c|c|c|c|}
\hline \multirow[t]{2}{*}{ Site name } & \multirow[t]{2}{*}{$N$} & \multicolumn{3}{|c|}{ TEC GPP model } & \multicolumn{3}{|c|}{ MOD17A2 GPP } \\
\hline & & Bias & RMSE & $r$ & Bias & RMSE & $r$ \\
\hline Bartlett & 24 & 0.50 & 1.00 & 0.97 & 0.71 & 1.72 & 0.89 \\
\hline MetoliusI & 36 & -0.63 & 1.83 & 0.71 & -1.04 & 1.93 & 0.71 \\
\hline MetoliusN & 24 & -0.73 & 1.07 & 0.88 & 0.26 & 0.84 & 0.87 \\
\hline Mize & 48 & 1.17 & 2.43 & 0.66 & 1.55 & 2.78 & 0.54 \\
\hline Morgan & 36 & 0.31 & 1.58 & 0.96 & -0.19 & 2.52 & 0.88 \\
\hline UMBS & 36 & 0.62 & 1.31 & 0.96 & 0.49 & 1.60 & 0.92 \\
\hline WindR & 24 & -0.93 & 1.99 & 0.88 & -0.16 & 1.23 & 0.88 \\
\hline Forest sites & 228 & 0.04 & 1.60 & 0.87 & 0.23 & 1.80 & 0.82 \\
\hline SGP & 36 & 0.45 & 1.52 & 0.46 & 0.74 & 1.52 & 0.49 \\
\hline Bondville & 48 & -0.57 & 2.42 & 0.90 & -0.88 & 3.14 & 0.85 \\
\hline FermiA & 24 & -0.33 & 2.47 & 0.92 & -1.06 & 4.08 & 0.75 \\
\hline MeadI & 48 & -0.20 & 3.64 & 0.91 & -1.70 & 5.40 & 0.87 \\
\hline MeadIR & 48 & -0.57 & 3.32 & 0.92 & -1.06 & 4.66 & 0.77 \\
\hline MeadR & 48 & -0.50 & 2.82 & 0.94 & -0.62 & 1.49 & 0.79 \\
\hline Crop sites & 252 & -0.16 & 2.67 & 0.86 & -0.76 & 3.38 & 0.77 \\
\hline FermiP & 24 & -0.83 & 2.12 & 0.89 & -1.54 & 3.04 & 0.88 \\
\hline Barrow & 24 & -2.71 & 3.91 & 0.77 & -3.25 & 4.52 & 0.79 \\
\hline Santa & 36 & 0.43 & 0.60 & 0.90 & 0.09 & 0.67 & 0.76 \\
\hline Tonzi & 48 & -0.92 & 1.49 & 0.79 & -0.19 & 1.04 & 0.88 \\
\hline Vaira & 60 & 0.63 & 2.32 & 0.64 & 0.48 & 2.43 & 0.57 \\
\hline Grass sites & 192 & -0.40 & 2.05 & 0.81 & -0.88 & 2.34 & 0.78 \\
\hline All sites & 672 & -0.05 & 2.20 & 0.85 & -0.31 & 2.82 & 0.73 \\
\hline
\end{tabular}

water stress, ARTS $E$ and flux $E$ increased with an increase of $E_{\mathrm{PT}}$ and vice versa, i.e., $E$ was controlled by energy supply $E_{\mathrm{PT}}$ (Fig. $4 \mathrm{e}$ ). A $r$ of 0.70 between TEC $E / E_{\mathrm{PT}} v s$. flux $E / E_{\mathrm{PT}}$ was obtained (Fig. $4 \mathrm{i}$ ).

Mize site has dry mild winters (November-March), warm dry springs (April and May), warm humid summers (June-October), with $52 \%$ of annual precipitation ( $1228 \mathrm{~mm} \mathrm{yr}^{-1}$ ) falling during the summer months. Due to abundant precipitation, $E$ was dominantly controlled by energy (Fig. 4f) and TEC had a stable $E / E_{\mathrm{PT}}$ of about 0.7 (Fig. 4c) except an obvious low value of 0.45 in April, 2004 subject to an drought event, which was successfully captured by ARTS $E$ (Fig. 4f) and TEC GPP (Fig. 2). Due to no obvious seasonal variation, $E / E_{\mathrm{PT}}$ produced a lower $r$ of 0.24 between TEC $E / E_{\mathrm{PT}} v s$. flux $E / E_{\mathrm{PT}}$ (Fig. 4j).

It can be concluded that TEC $E / E_{\mathrm{PT}}$ often has a lower $r$ with flux $E$ / $E_{\mathrm{PT}}$ at wet sites with plentiful water supply (i.e., forest or irrigated crop land) because $E$ variations are mainly driven by energy supply (i.e., $E_{\mathrm{PT}}$ ). In other words, $E / E_{\mathrm{PT}}$ dose not play a water stress effect on GPP estimation in a humid environment, thus a low $r$ of TEC $E / E_{\mathrm{PT}}$ $v s$. flux $E / E_{\mathrm{PT}}$ dose not deteriorate the accuracy of GPP prediction. For instance, TEC $E / E_{\mathrm{PT}}$ had a low $r=-0.06$ at Bartlett (Fig. 3b), but TEC GPP still had a higher $r=0.97$ with observed GPP at Bartlett (Fig. 2).

\subsection{Comparison of water stress factor of $\mathrm{E} / \mathrm{E}_{P T}$ and $\mathrm{E} / R_{n}$ at site level}

As $E / R_{\mathrm{n}}$ is also capable of indicating water stress as used in EC-LUE model (Yuan et al., 2007) similarly to $E / E_{\mathrm{PT}}$ adopted in this study, we evaluated their potential in representing water stress effect in two ways. First, we calculated a new TEC GPP ${ }_{R n}$ for all sites on monthly scale with $W_{\varepsilon}$ defined as $E / R_{\mathrm{n}}$ to substitute for $E / E_{\mathrm{PT}}$ in Eq. (5). Fig. 5 shows that TEC GPP ${ }_{R \mathrm{n}}$ had a statistic $(\mathrm{RMSE}=2.28$ $\mathrm{gC} \mathrm{m}^{-2} \mathrm{day}^{-1}$, bias $=-0.46 \mathrm{gC} \mathrm{m}^{-2} \mathrm{day}^{-1}$, and $r=0.84$ ) slightly worse than that of original TEC GPP.

Second, because water stress factor inferred from vapor pressure deficit $(D)$ and/or soil moisture (SM) has been used in some GPP models (Table 1 ), $D$ and SM-derived water stress factor as an independent variable has a potential to evaluate other form of water stress factor such as $E / E_{\mathrm{PT}}$ and $E / R_{\mathrm{n}}$. According to the definition of water stress factor $W_{\varepsilon}$ in 3-PG model (Landsberg and Waring, 1997), we calculated vapor 



Fig. 2. Comparison of seasonal variations of the observed flux tower GPP vs. estimated TEC and MOD17 monthly average GPP at 18 flux sites. Note that only C4 sites are labeled. 


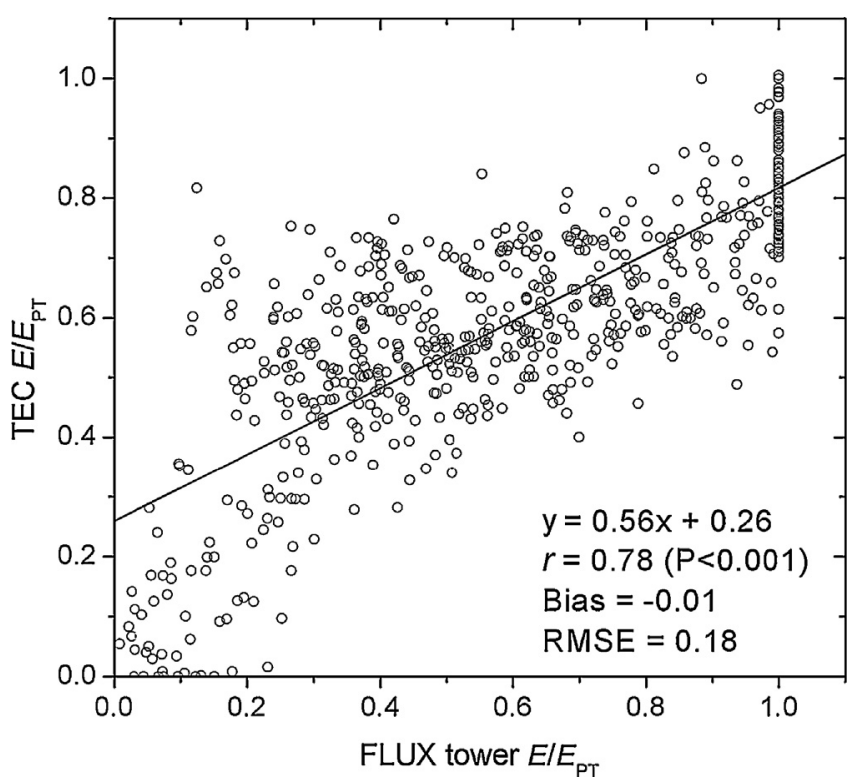

Fig. 3. Scatterplots of the observed monthly Flux $E / E_{\mathrm{PT}} v s$. TEC $E / E_{\mathrm{PT}}$ for all data at 18 flux sites.

pressure deficit modifier $f(D)$ and soil water modifier $f(S M)$ from scaled volume soil water content observed at flux sites and then used the minimum of $f(D)$ and $f(\mathrm{SM})$ as 3-PG $W_{\varepsilon}$ and in addition multiplied $f(D)$ and $f(\mathrm{SM})$ to infer a new $W_{\varepsilon 1}$ (i.e., $f(D) \times f(\mathrm{SM})$ ).
Further correlation analysis of $3-\mathrm{PG} W_{\varepsilon} v s . E / R_{\mathrm{n}}$ and $E / E_{\mathrm{PT}}$ (Fig. 6a) shows that 3-PG $W_{\varepsilon}$ had a higher $r$ with $E / E_{\mathrm{PT}}$ than that with $E / R_{\mathrm{n}}$ at 11 sites (except one site, Bartlett). The new $W_{\varepsilon 1}$ (i.e., $f(D) \times f(\mathrm{SM})$ ) also had a higher $r$ with $E / E_{\mathrm{PT}}$ compared with $E / R_{\mathrm{n}}$ (Fig. 6b). Thus, it can be seen that the minimum of $f(D)$ and $f(S M)$ and the product of $f(D)$ and $f(\mathrm{SM})$ as a water stress factor in different form had a similar capacity in exerting the water stress effect (Fig. 6c). Note that six sites (MeadI, MeadIR, MeadR, Mize, Morgan, and UMBS) are not considered in Fig. 6 because there is no observed SM data for these sites. Overall, $E / E_{\mathrm{PT}}$ appears superior to $E / R_{\mathrm{n}}$ in representing water stress in the frame of TEC GPP model. In addition, $E / E_{\mathrm{PET}}$-based drought severity index (DSI) has been successfully applied to study the variation of global drought (Mu et al., 2013).

\subsection{Comparison with MOD17A2 GPP and other GPP models}

The original 8-day MOD17A2 GPP products were averaged to monthly GPP and compared with flux tower GPP data and TEC GPP data at monthly temporal scales. The MOD17A2 GPP predicted monthly average GPP for all sites (samples $=672$ ) with overall statistics of $r=0.73$, RMSE $=2.82 \mathrm{gC} \mathrm{m}^{-2} \mathrm{day}^{-1}$, and bias $=-0.31 \mathrm{gC}$ $\mathrm{m}^{-2} \mathrm{day}^{-1}$ (Fig. 1a). Thus, TEC GPP had a better statistical performance than MOD17A2 GPP (Fig. 1a and Table 3). For the forest sites, TEC GPP had an $r$ of 0.87 and an RMSE of $1.60 \mathrm{gC} \mathrm{m}^{-2}$ day $^{-1}$, while MOD17A2 GPP had an $r$ of 0.82 and an RMSE of $1.80 \mathrm{gC} \mathrm{m}^{-2} \mathrm{day}^{-1}$. For the crop sites, an $r$ of 0.86 and an RMSE of $2.67 \mathrm{gC} \mathrm{m}^{-2}$ day $^{-1}$ were found for TEC GPP, while MOD17A2 GPP
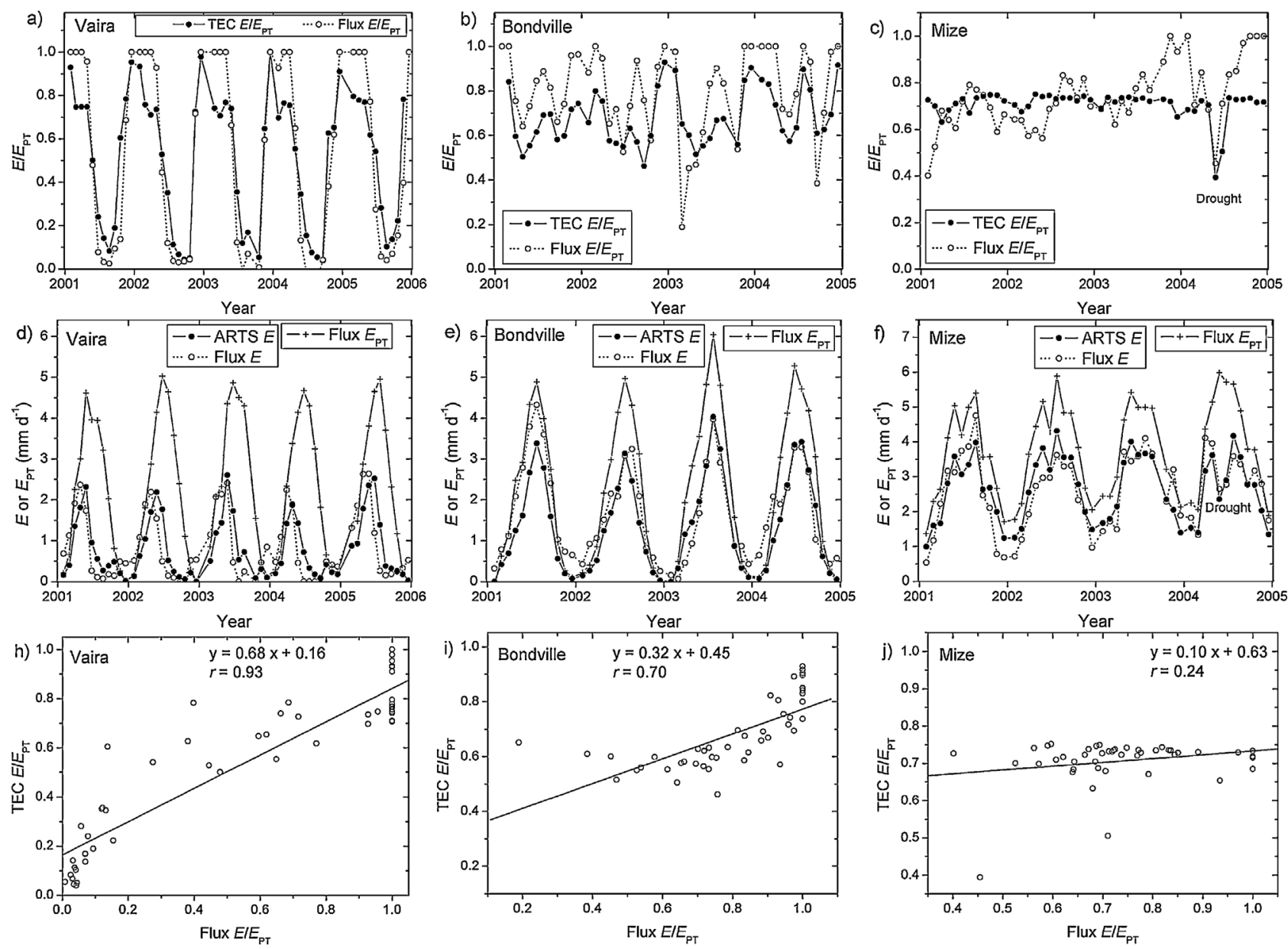

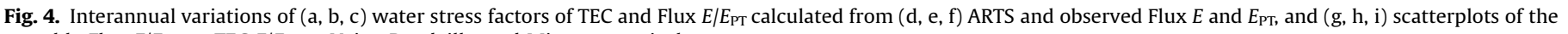
monthly Flux $E / E_{\mathrm{PT}} v s$. TEC E/E $E_{\mathrm{PT}}$ at Vaira, Bondville, and Mize, respectively. 


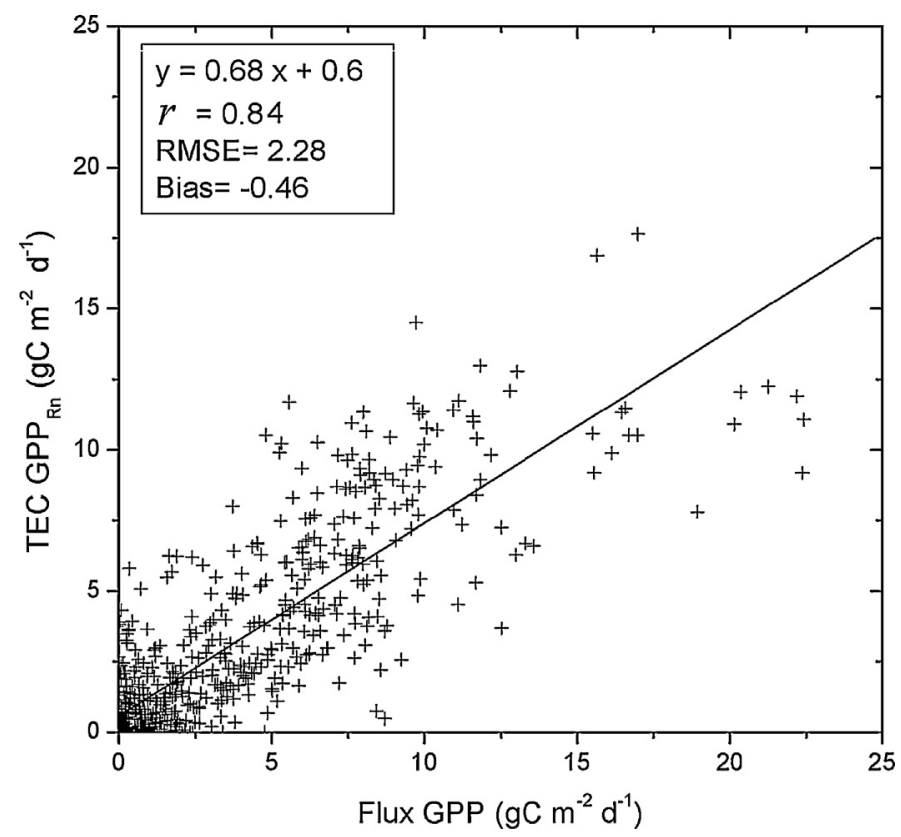

Fig. 5. Scatterplots of the observed Flux tower GPP $v s$. estimated TEC GPP ${ }_{R \mathrm{n}}$ driven with $E / R_{\mathrm{n}}$ as a water stress factor.

had an $r$ of 0.77 and an RMSE of $3.38 \mathrm{gC} \mathrm{m}^{-2} \mathrm{day}^{-1}$. For the grass sites, TEC GPP had an $r$ of 0.81 and an RMSE of $2.05 \mathrm{gC} \mathrm{m}^{-2} \mathrm{day}^{-1}$, while MOD17A2 GPP had an $r$ of 0.78 and an RMSE of $2.34 \mathrm{gC} \mathrm{m}^{-2} \mathrm{day}^{-1}$. Both TEC GPP and MOD17A2 GPP estimates were more accurate for forest ecosystems than that for non-forest ecosystems. A similar result was reported by Yang et al. (2007) and Heinsch et al. (2006). Yearly estimated MOD17A2 GPP (Fig. 1b) showed better performance $\left(\mathrm{RMSE}=1.03 \mathrm{gC} \mathrm{m}^{-2} \mathrm{day}^{-1}\right.$, bias $=$ $-0.35 \mathrm{gC} \mathrm{m}^{-2} \mathrm{day}^{-1}$, and $\left.r=0.75\right)$ relative to monthly MOD17A2 GPP.

The MOD17A2 GPP showed an obvious under-estimation with a bias of -0.76 and $-0.88 \mathrm{gC} \mathrm{m}^{-2} \mathrm{day}^{-1}$ for crop and grass sites, respectively, which is consistent with the analysis of Yang et al. (2007) and Zhang et al. (2008). Recently, Sjöström et al. (2013) also reported MODIS underestimates GPP at dry sites located in the African Sahel region, while TEC GPP had a better performance with a lower bias of -0.16 and $-0.40 \mathrm{gC} \mathrm{m}^{-2} \mathrm{day}^{-1}$ for crop and grass sites (Table 2).

Fig. 2 indicates that the obvious under-estimation of MOD17A2 GPP often occurred at six sites with C4 crop and grass including Bondville, FermiA, MeadI, MeadIR, MeadR, and FermiP. For example, MeadIR crop site was planted with continuous C4 maize, and FermiP grass site was covered with $\mathrm{C} 4$ grasses and forbs. Fig. 1c shows that for C4 plants at six sites, MOD17A2 GPP had a worse performance $\left(\right.$ RMSE $=4.33 \mathrm{gC} \mathrm{m}^{-2} \mathrm{day}^{-1}$, bias $=-1.45 \mathrm{gC} \mathrm{m}^{-2} \mathrm{day}^{-1}$, and $r=0.83$ ) (Fig. 1c) compared with monthly TEC GPP.

The under-estimation of MOD17A2 GPP was partly due to neglecting the difference of $\mathrm{C} 3$ and $\mathrm{C} 4$ species because leaf photosynthetic rates of $\mathrm{C} 4$ species are greater than those of $\mathrm{C} 3$ species (Jones, 1992; Pearcy and Ehleringer, 1984; Prince and Goward, 1995; Baldocchi, 1994; Verma et al., 2005). To solve such GPP estimation error induced by C3 and C4 species, the TEC GPP model (similar to GLO-PEM GPP model, Prince and Goward, 1995) adopted different maximum light use efficiency $\left(\varepsilon^{*}\right)$ for C3 and C4 species. C4 $\varepsilon^{*}$ was only adopted when C4 crop was planted in field according to the plantation record. Similarly, C3 $\varepsilon^{*}$ was just applied to $\mathrm{C} 3$ crop in the TEC model. Explicit consideration of C3 and C4 crop is the main merit of TEC GPP model. However, a) $\operatorname{Min}(f(D), f(S M))$

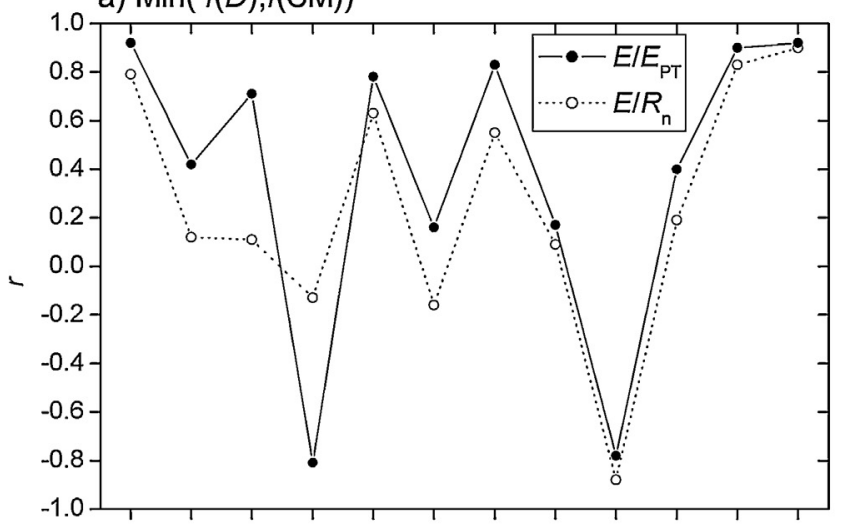

b) $f(D) \times f(S M)$

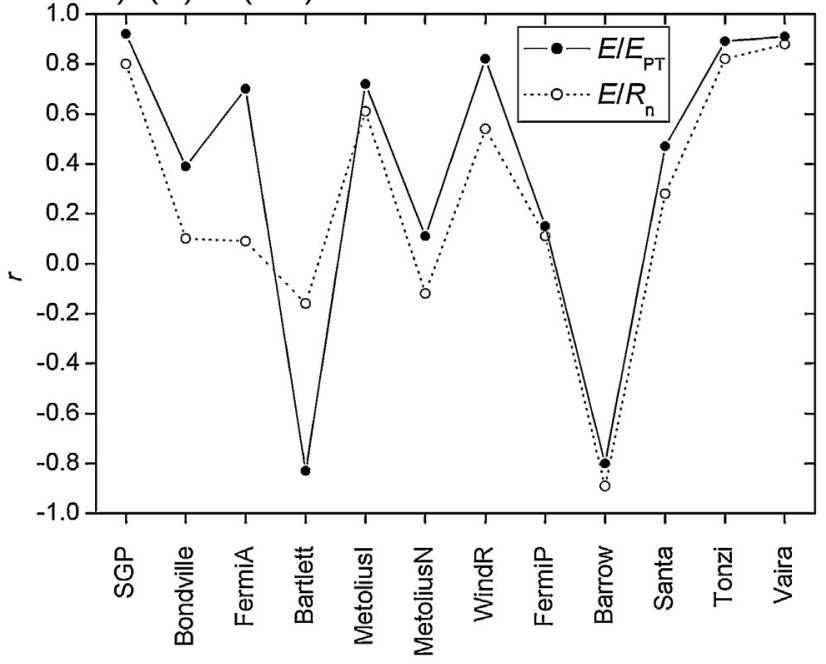

c) $f(D) \times f(S M)$ vs. $\operatorname{Min}(f(D), f(S M))$

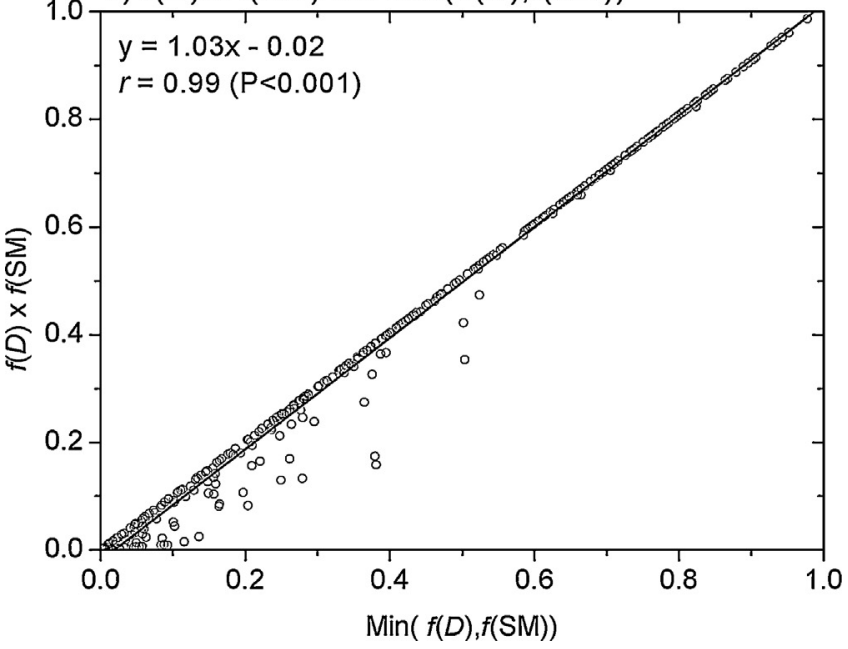

Fig. 6. Correlation coefficient $r$ of (a) the minimum of $f(D)$ and $f(\mathrm{SM}) v s$. $E / E_{\mathrm{PT}}$ and $E /$ $R_{\mathrm{n}}$ and (b) the product of $f(D)$ and $f(\mathrm{SM}) v s . E / E_{\mathrm{PT}}$ and $E / R_{\mathrm{n}}$ at 12 flux sites respectively, and (c) scatterplots of the minimum of $f(D)$ and $f(\mathrm{SM}) v$ s. $f(D) \times f(\mathrm{SM})$.

MOD17A2 GPP does not distinguish C4 species from C3 species as a global GPP model. The resultant error implies that it is essential to take into account the spatial distribution of $\mathrm{C} 3$ and $\mathrm{C} 4$ species in modeling global land GPP.

Some previous GPP models, due to calibration of $\varepsilon^{*}$ as an essential prerequisite, perform better than TEC GPP model. For example, the EC_LUE model can explain $77 \%$ variations across 


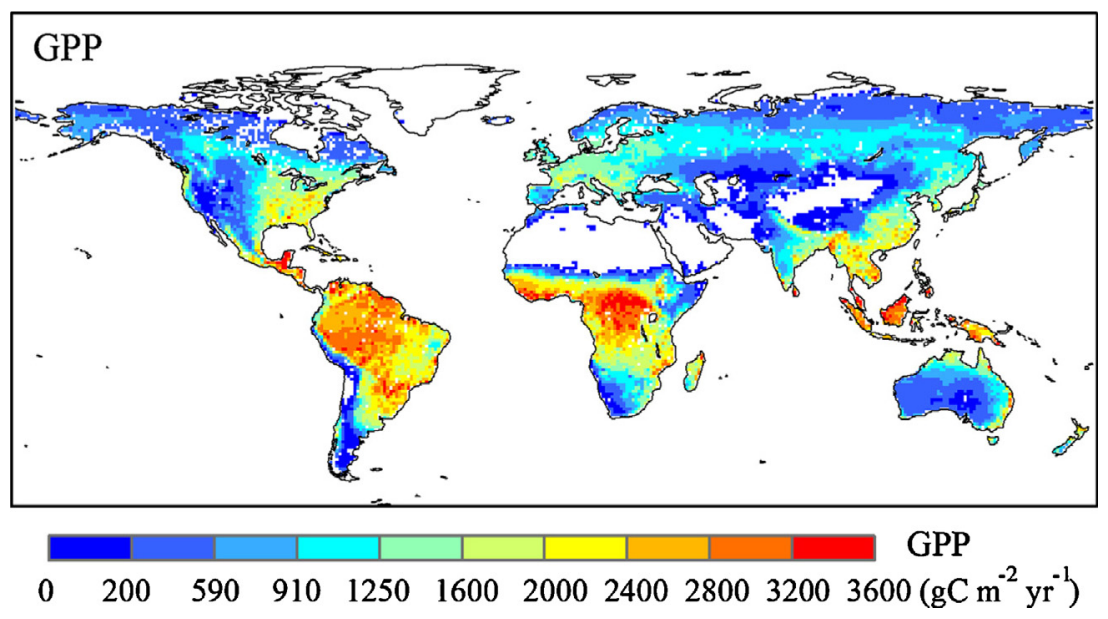

Fig. 7. Global annual TEC GPP averaged from 2000 to 2010.

16 America flux sites (Yuan et al., 2007) and 79\% and 62\% of the GPP variation at 32 Asian sites with C3 and C4 vegetation (Li et al., 2013), while the TEC GPP model just explains 71\% variations across 18 flux sites on monthly scale. The SVM model predicted GPP for 24 available Ameriflux sites with an RMSE of $1.87 \mathrm{gC} \mathrm{m}^{-2} \mathrm{day}^{-1}$ and an $r$ of 0.84 (Yang et al., 2007) while TEC GPP model had statistics of a higher RMSE of $2.20 \mathrm{gC} \mathrm{m}^{-2}$ day $^{-1}$ and a same $r$ of 0.84 . The SVM model was trained with a large number of GPP data examples from AmeriFlux 33 flux sites and the EC_LUE model was developed with GPP training data from 12 flux sites. Unlike the previous two models, the TEC GPP model adopted a published $\varepsilon^{*}$ of 1.8 and $2.73 \mathrm{gC} \mathrm{MJ}^{-1}$ for $\mathrm{C} 3$ and $\mathrm{C} 4$ species, respectively. As a result, the TEC GPP model had the advantage that it can more easily be applied to large areas due to no need of additional calibration.

\subsection{Global estimation of TEC GPP}

Global land TEC GPP over 11 years from 2000 to 2010 was estimated using monthly MODIS FPAR and ECMWF ERA reanalysis data at $1.0^{\circ}$ spatial resolution. Fig. 7 shows the spatial distribution of annual TEC GPP that further indicates the regulation of climate. Warm and humid climate zones often corresponded to a high GPP; tropical and subtropical forests in South America, Africa, and Asia Island had a high GPP of $2000 \mathrm{gC} \mathrm{m}^{-2} \mathrm{yr}^{-1}$. In contrast, cold and dry climate zones usually featured a low GPP due to stressed effect of low temperature or precipitation; the major deserts of North Africa, Middle East, Middle Asia, and Australia, as well as highlatitude regions in the northern hemisphere, had a GPP less than $590 \mathrm{gC} \mathrm{m}^{-2} \mathrm{yr}^{-1}$. Such spatial pattern of global GPP was consistent with previous results (Sasai et al., 2007; Yuan et al., 2010; Jung et al., 2011).

Fig. 8 shows that the TEC model estimated a mean annual land GPP of $128.2 \mathrm{PgC} \mathrm{yr}^{-1}$ with a standard deviation of $1.5 \mathrm{PgC} \mathrm{yr}^{-1}$, which falls in the range of published global GPP estimates that consider the effect of $\mathrm{C} 4$ and $\mathrm{C} 3$ species, respectively. For instance, BESS model quantified the global GPP as $118 \pm 26 \mathrm{PgC}_{\mathrm{yr}}^{-1}$ between 2001 and 2003 (Ryu et al., 2011) and a multi-model analysis based on FLUXNET gave an average GPP estimate of $123 \pm 8 \mathrm{PgC} \mathrm{yr}^{-1}$ during the period of 1998 to 2005 (Beer et al., 2010); MTE model presented a global GPP estimate of $119 \pm 6 \mathrm{Pg}$ $\mathrm{Cyr}^{-1}$ over the period of 1982-2008 (Jung et al., 2011); BEAMS model obtained an average annual GPP of $131.5 \mathrm{Pg} \mathrm{Cyr}^{-1}$ for the period of 2001-2004 (Sasai et al., 2007). In addition, the Simple Biosphere Model (SIB), coupled with global distribution of C4 and C3 vegetation, estimated a higher GPP of $150 \mathrm{Pg} \mathrm{C} \mathrm{yr}^{-1}$ (Still et al., 2003).
The global GPP value calculated by TEC model was obviously higher than the estimates of EC-LUE and MOD17 models regardless of C4 plant effect. EC-LUE model presented an annual mean GPP value of $110 \mathrm{PgCyr}^{-1}$ for 2000-2003 (Yuan et al., 2010);

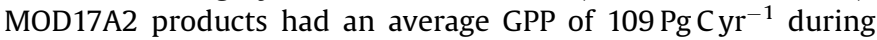
the period of 2001-2003 (Zhao et al., 2005) and recent MOD17A3 products gave an average GPP of $114.3 \pm 0.9 \mathrm{PgC}_{\mathrm{yr}}^{-1}$ (Fig. 8). This reveals that regardless of $\mathrm{C} 4$ species can result in an underestimated global GPP.

Fig. 9 presents the latitudinal variation of C4 and C3 annual land TEC GPP. C4 GPP reached a global maximum at latitude between $0^{\circ} \mathrm{N}$ and $20^{\circ} \mathrm{N}$, which was consistent with Still et al. (2003). The modeled TEC GPP for C4 plants was $40.3 \pm 1.1 \mathrm{Pg} \mathrm{C} \mathrm{yr}^{-1}$ similar to $35.3 \mathrm{Pg} \mathrm{C} \mathrm{yr}^{-1}$ given by Still et al. (2003) and contributed $31.6 \%$ to global GPP, which was close to $27 \%$ obtained by Fung et al. (1997) but higher than some previous estimates of $23 \%$ and 20\% (Still et al., 2003; Beer et al., 2010).

Global TEC GPP estimates (Fig. 8) had no significant trend from 2000 to 2010 (slope of $k=0.07, P=0.66$ ), which was consistent with the result of MOD17A3 GPP (slope $k=0.02, P=0.81$ ) and satellite observations of vegetation activity (Samanta et al., 2011). Further comparison of trends of TEC and MOD17A3 GPP (Fig. 10a and c) indicates an increase in eastern Russia, China, India, central African, western North America, and a decrease in western Russia, tropical Asia, Australia, southern South America by both models. Large differences were found in central North America where TEC

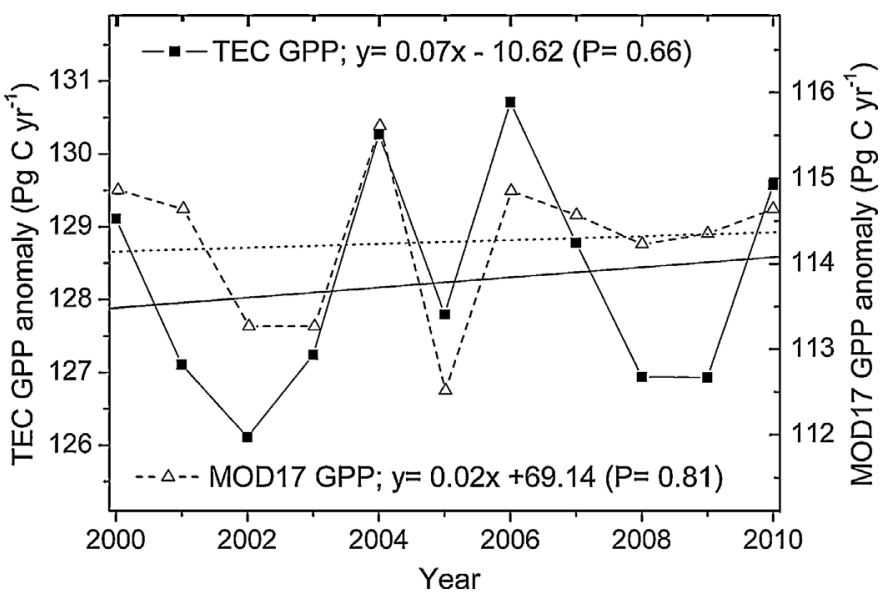

Fig. 8. Annual global land TEC and MOD17A3 GPP anomalies from 2000 to 2010 and corresponding linear trend. 


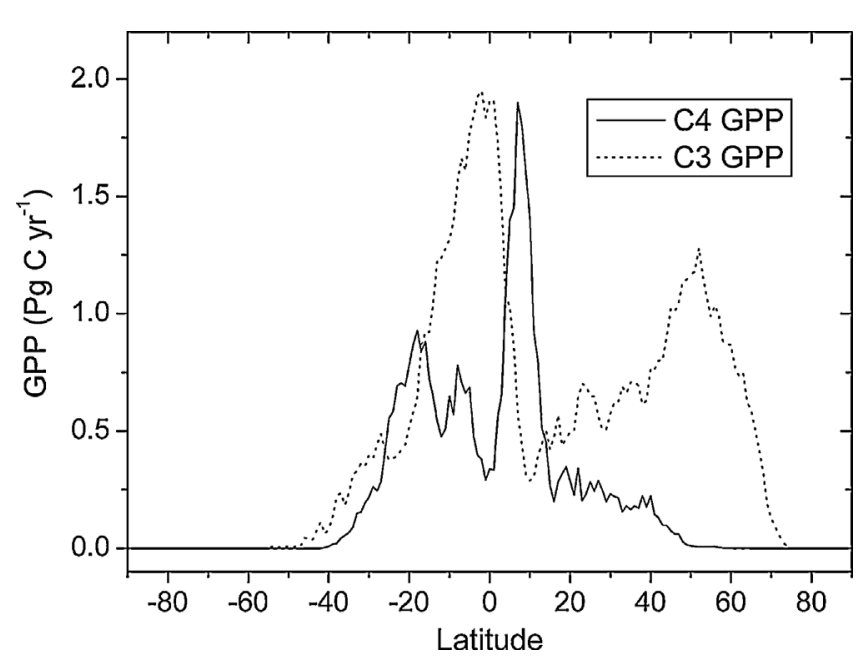

Fig. 9. Latitudinal mean $\left(-90^{\circ} \mathrm{S}-90^{\circ} \mathrm{N}\right)$ of $\mathrm{C} 4$ and $\mathrm{C} 3$ annual global land TEC GPP.

and MOD17A3 GPP showed opposite but not statistically significant trends. Indeed, significance analysis of linear trend (Fig. 10b and d) indicates that most variations of global land GPP for period of 2000-2010 were not statistically significant.

\section{Discussion}

The TEC, CASA and EC-LUE GPP models similar to TEM (Raich et al., 1991) and BESS (Ryu et al., 2011) physiological models apply a scalar (often defined as the ratio of $E$ to $E_{\mathrm{Th}}, A$, or $E_{\mathrm{PT}}$ ) to infer water stress on GPP or NPP because the ratio scalar is capable of showing climatic supply/demand control on vegetation productivity (Churkina et al., 1999). One more merit of such GPP models is that they all adopt a universal $\varepsilon^{*}$ for $C 3$ species due to use of evaporation ratio as the water stress factor. However,
Thornthwaite (1948) temperature-based $E_{\mathrm{Th}}$ adopted in CASA NPP model (Potter et al., 1993) and available energy $A$ used in EC-LUE GPP model (Yuan et al., 2007) are not real potential evaporation $\left(E_{\mathrm{P}}\right)$ in concept because $E_{\mathrm{P}}$ should include contributions of temperature and available energy according to Penman (1948) evaporation theory. Thus TEC model was prior to CASA and EC-LUE models in defining the water stress factor as $E / E_{\mathrm{PT}}$ because $E_{\mathrm{PT}}$, calculated from temperature and net radiation, represents the potential evaporation over wet surface (Priestley and Taylor, 1972). Fig. 6 shows $E / E_{\mathrm{PT}}$ had a better performance than $E / R_{\mathrm{n}}$ in expressing water stress effect. In addition, $E_{\mathrm{PT}}$ subtracted from annual precipitation is used as a water balance coefficient to evaluate water budget limitations on NPP (Churkina et al., 1999). Note that Priestley-Taylor $E_{\mathrm{PT}}$ equation defines aerodynamic forcing term as a constant percent of radiation forcing term and hence neglects the highly variable effect of wind speed and atmospheric humidity, while Penman-Monteith type of $E_{\mathrm{P}}$ equation, due to physically considering the contribution of aerodynamic forcing term and radiation forcing term, might be preferred in representing $E_{\mathrm{P}}$.

Numerous LUE models, such as MOD17A2 GPP, 3-PG model, and the CFLUX model, adopt $D$ and/or SM to describe water stress effect as a physiological control over plant productivity. As a result, they often require biome-related $\varepsilon^{*}$ as input variables (Table 1 ) to compensate for the lack of uniform environmental constraint equations to LUE among various C3 biome types (Yuan et al., 2010). This limits large scale applications of GPP prediction due to classification error from various C3 biome types.

As TEC GPP model includes a new water stress factor and treats C3 and C4 plants separately, it is necessary to quantify the relative importance of the two innovations. Driven with the new water stress factor and the universal $\mathrm{C} 3 \varepsilon^{*}$ of $1.8 \mathrm{gC} \mathrm{MJ}^{-1}$ applied for all data, TEC model predicted monthly average GPP for all sites (samples $=672$ ) with an improved statistics of $r=0.81$, RMSE $=$ $2.43 \mathrm{gC} \mathrm{m}^{-2} \mathrm{day}^{-1}$, and bias $=-0.39 \mathrm{gC} \mathrm{m}^{-2} \mathrm{day}^{-1}$. Further addition of the separate treatment of C3 and C4 plants in TEC GPP model



Fig. 10. Distribution of global trend of (a) TEC GPP and (c) MOD17A3 GPP and (b and d) their significance (samples=11) of linear trend for period of 2000-2010. 
produced a better overall statistics of $r=0.85$, RMSE $=2.2 \mathrm{gC} \mathrm{m}^{-2}$ day $^{-1}$, and bias $=-0.05 \mathrm{gC} \mathrm{m}^{-2} \mathrm{day}^{-1}$ for all data. In short, the two innovations independently played a positive effect in improving GPP estimation, but the new water stress factor played an essential role in building the TEC GPP process model.

The TEC GPP model as a novel GPP model can be easily applied to large areas with aid of distribution map of C3 and C4 biomes because it explicitly considered the difference of $\mathrm{C} 3$ and C4 ecosystems besides water stress impact. However, most previous satellite-based GPP progress models do not distinguish between C3 and C4 species except GLO-PEM model and a revised CASA model (Still et al., 2003). Note that some biopyhsical models such as Boreal Ecosystem Productivity Simulator (BEPS; Chen et al., 2012) and BESS (Ryu et al., 2011) use biochemical leaf photosynthesis models for C3 (Farquhar et al., 1980) and C4 plants (Collatz et al., 1992), respectively, i.e., they do not need remote sensing FPAR data.

As water stress reduces the GPP especially when drought occurs (Nightingale et al., 2007; Leuning et al., 2005), thus, how different water stress constraints (SM, $D, E / E_{\mathrm{PT}}$, and $\mathrm{EF}$ ) or their combinations would result in different GPP behavior in drought events has gained much attention. Mu et al. (2007) found that $D$ signals easily decouple with soil moisture dynamics especially at summer monsoon-dominated climate regions such as China, which shows that $D$ and SM play a distinctive role in stressing GPP. In addition, soil moisture as an independent stress factor affects stomatal conductance and GPP as well (Jarvis, 1976). However, the MOD17 method uses $f(D)$ to account for the effects of atmospheric demand for water vapor on GPP but neglecting soil water stress (Leuning et al., 2005). As a result, MOD17 overestimated GPP at a tropical wet/dry savanna site during the dry season (Leuning et al., 2005) and in eco-regions with substantial drought (Nightingale et al., 2007). We also found that MOD17 GPP missed a drought event in April, 2004 at Mize (Figs. 2 and 4f).

Besides, drought effect on interannual variations of global GPP has drawn much attention. Zhao and Running (2010) initially pointed out drought-induced reduction in global terrestrial NPP from 2000 through 2009 based on MOD17 GPP products. However, Medlyn (2011) argued that it is the water stress effect due to rising $D$ that decreases MOD17 NPP at higher temperatures. Hashimoto et al. (2013) further scrutinized the model responses to drought by using different sets of simulations with $D$ and/or SM-based drought stress functions within the TOPS (Nemani et al., 2009) modeling frameworks. He found that TOPS simulations with a $D$-control-only-function underestimate GPP trend during the period 2000-2009 because of over-sensitivity to $D$ drought effects. Thus, many global GPP models such as CFLUX model, TOPS model, GLO-PEM model, and 3-PG model, incorporate both $D$ and SM as modification functions of LUE because they show very different behavior in space and time. In contrast with the accepted water stress factor (i.e., $f(\mathrm{D}) \times f(\mathrm{SM})$ ), we found that $E / E_{\mathrm{PT}}$ was better than $E / R_{\mathrm{n}}$ in expressing the effect of water stress (Fig. 6).

However, as physiological control (i.e., $f(\mathrm{D}) \times f(\mathrm{SM})$ ) and supply/ demand control (i.e., $E / E_{\mathrm{PT}}$ ) are different types of water stress factor in concept (Churkina et al., 1999), then the question is whether they play a same role in describing the water stress effect on GPP. Fig. 11 a also shows that both water stress factors, i.e., $f(\mathrm{D}) \times f(\mathrm{SM})$ and $E / E_{\mathrm{PT}}$, can successfully capture summer drought at Vaira characterized by obvious interannual variations of SM and $D$ (Fig. $11 \mathrm{~b}$ ). Another common feature is that $f(\mathrm{D}) \times f(\mathrm{SM})$ or $E / E_{\mathrm{PT}}$ has a high value above 0.9 in winter, i.e., there is no water stress effect in non-growing season at three sites (Fig. 11a, c, and e). But they feature different variations in summer at Bondvill crop site (Fig. 11c) and Bartlett forest site (Fig. 11e), i.e., $f(\mathrm{D}) \times f(\mathrm{SM})$ tends to exert a water stressing effect even in summer featuring plentiful water supply (i.e., $f(\mathrm{SM})=1.0$ ) because $f(D)$ is anti-correlated with an increase in $D$ (Fig. 11d and f), whereas $E / E_{\mathrm{PT}}$ indeed tends to show an increasing energy supply in summer because energy controls the variations of $E$ and GPP at sites with plentiful water supply (Fig. 11c and e). This implies that GPP models with a $f(D)$-control-only or a combined- $f(D) \times f(\mathrm{SM})$ control simulation tend to underestimate GPP trend in wet summer, which might lead to a wrong assessment of climate change impact on carbon cycle. It is consistent with the findings of Hashimoto et al. (2013) that a $f(D)$-control-only simulation by TOPS model underestimates GPP during the period 2000-2009 because of over-sensitivity to $D$ drought effects. To our knowledge, the distinctive difference of physiological control (i.e., $f(\mathrm{D}) \times f(\mathrm{SM})$ ) and supply/demand control (i.e., $E / E_{\mathrm{PT}}$ ) on GPP in summer has seldom been addressed in previous studies.

There are a number of possible reasons for the differences of TEC GPP and flux tower GPP. They are satellite-derived MODIS FPAR, water stress parameterization, scale issue, observation error of flux GPP, temperature stress parameterization, and maximum light-use efficiency, which also challenge other GPP models (Heinsch et al., 2006; Yuan et al., 2007).

Fig. 2 shows that TEC GPP for C4 species did not increase over $15 \mathrm{gC} \mathrm{m}^{-2}$ day $^{-1}$ whereas flux tower GPP reached $20 \mathrm{gC} \mathrm{m}^{-2}$ day $^{-1}$ for $\mathrm{C} 4$ species at FermiA, MeadI, MeadIR, and MeadR. What caused this obvious discrepancy between TEC GPP and tower GPP for C4 species? As there is no observed FPAR data at these flux sites, and LAI and FPAR often have an exponential relationship (Monteith, 1973), we had to compare MODIS LAI data with observed LAI data at flux sites of MeadI, MeaDIR, and MeadR (Fig. 12). Both irrigated sites, i.e., MeadI and MeadIR, featured a peak MODIS LAI of $\sim 2.0$ (Fig. 12a and b), while the observed peak LAI was $\sim 5.5$ for two years (Verma et al., 2005). Similarly, Fig. 12c shows that MODIS LAI data at the rainfed site of MeadR had a peak LAI of 2.3 for C3 soybean in 2002 and 1.6 for C4 maize in 2003, whereas the field peak LAI at MeadR had a peak LAI of 3.0 for soybean in 2002 and 4.3 for maize in 2003, respectively (Verma et al., 2005). Above comparisons show that MODIS LAI products significantly underestimated crop LAI. Furthermore, a lower LAI often corresponds to a lower FPAR due to their exponential relationship (Monteith, 1973), thus we can deduce that MODIS FPAR data was also underestimated which primarily caused the discrepancy between TEC GPP and flux tower GPP for C4 species. Accordingly, it is suggested to predict C4 GPP by using accurate remote sensing-FPAR and LAI data. On the other hand, it reveals that absence of continuous measurement of LAI and FPAR at flux sites hinders further improvement of remote sensing-based LAI/ FPAR products and so far ecological models such as GPP model. We will explore the discrepancy at SGP, FermiA, and Barrow when observed LAI/FPAR data are available.

Although satellite-based GPP products have been often validated with the flux tower GPP data (Heinsch et al., 2006; Xiao et al., 2005a; Yang et al., 2007; Yuan et al., 2007; Li et al., 2008), it should be kept in mind that flux tower GPP is not directly measured by eddy covariance at the tower sites and it is not a direct observation. The towers do directly measure net ecosystem exchange (NEE) and estimate respiration with a simple model (Falge et al., 2001). GPP comes from the difference between daytime NEE and daytime respiration (Falge et al., 2002), so the value given for GPP inherits all the uncertainties in the measurement of NEE and in the model for daytime respiration. Dragoni et al. (2007) found random uncertainty in NEE is $3-4 \%$ of annual NEP at a forest site. Respiration model is usually based on night-time measurements when there is no uptake and on assumptions about how respiration varies with temperature that is used to predict the daytime respiration (Falge et al., 2001). When the tower results are compared to the satellite-based GPP values, the uncertainties in flux GPP should be given attention. 


\section{a) Vaira}
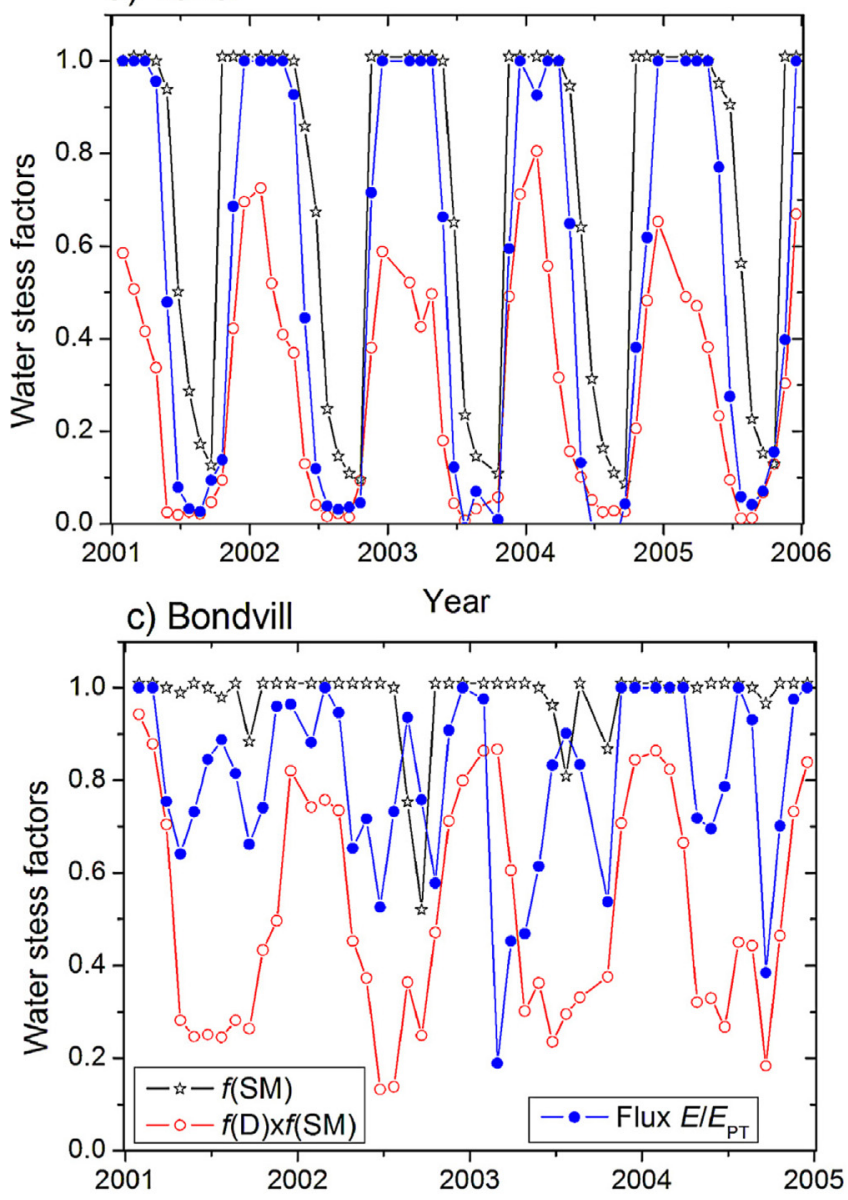

e) Bartlett

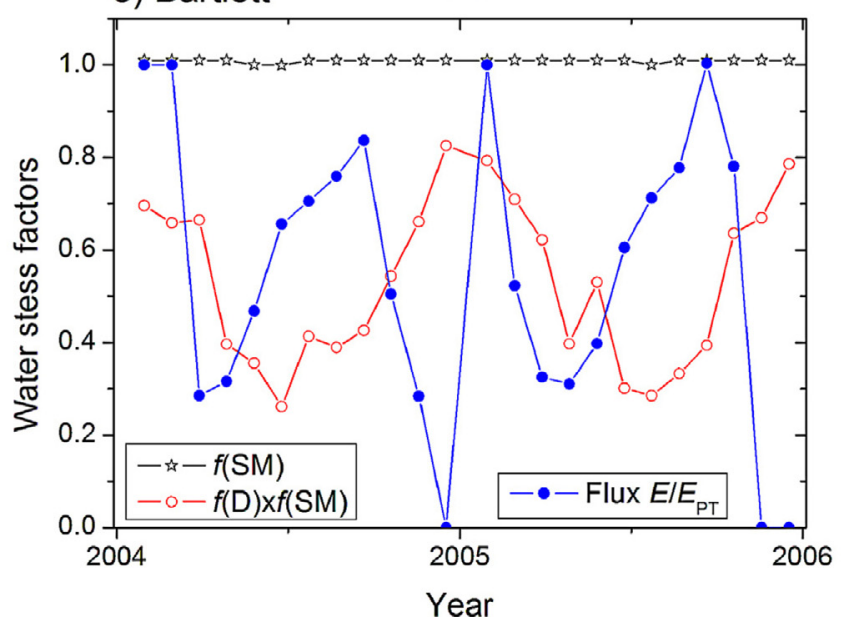

b) Vaira
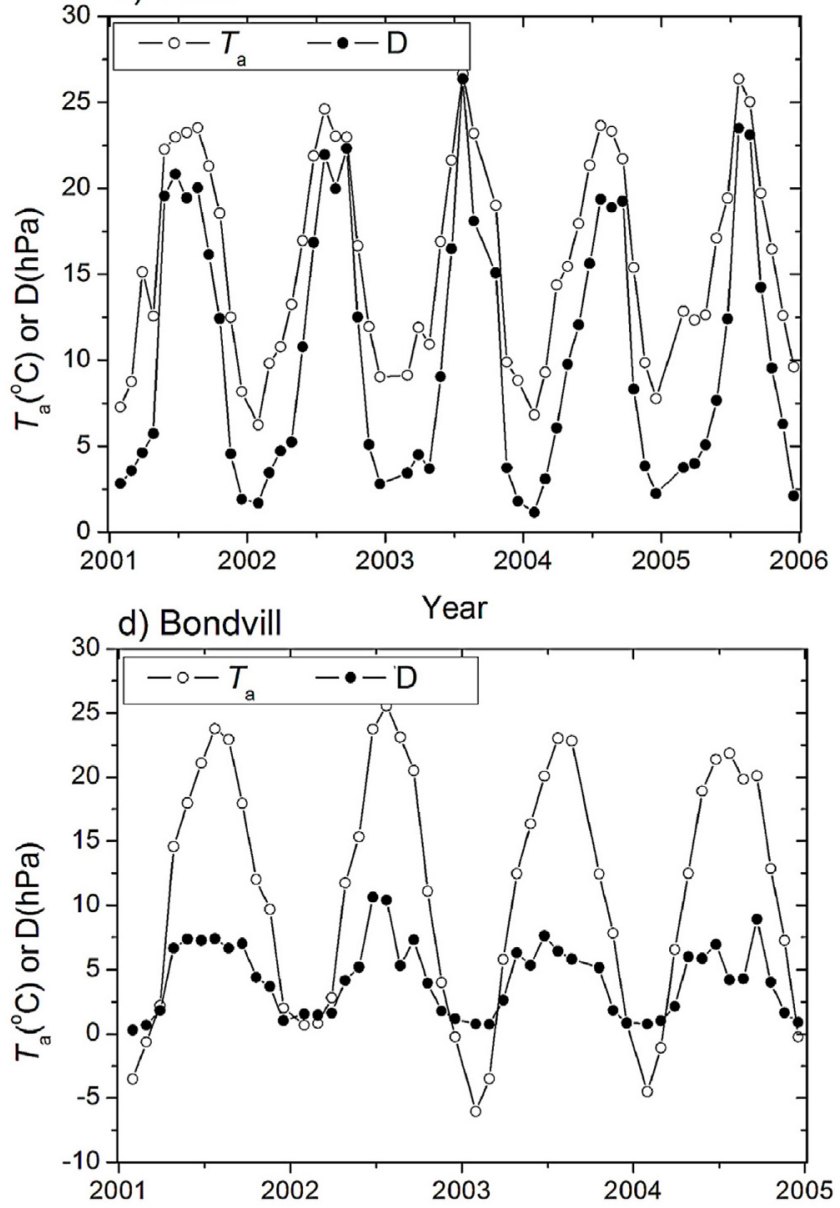

f) Bartlett

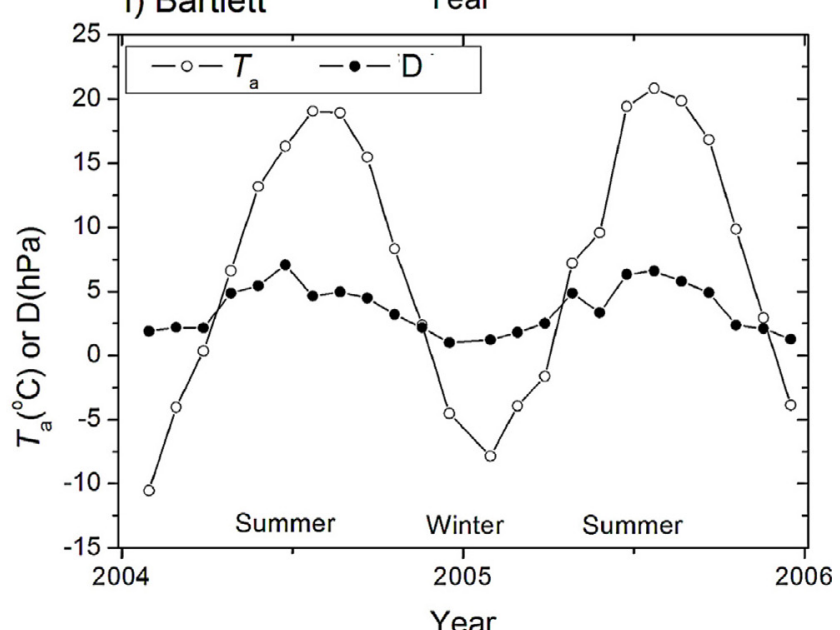

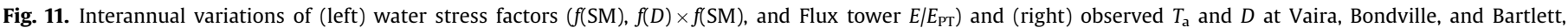
respectively.

Actually, there exists a vertical distribution of C3 and C4 species in savanna ecosystems, i.e., C4 species are understory whereas overstory is C3 species, which has never been considered in current global GPP models and therefore the global estimate of C4 GPP in the one-big-leaf GPP approach should be error-prone. However, TEC model ingested the horizontal distribution of C4 species in a format of percentage of C4 specie per unit area (Still et al., 2003) that could partly reduce the impact of vertical distribution of
C3 and C4 species. We will study this effect when the observation data of vertical distribution of C3 and C4 species is available.

Up to present, numerous models have been developed to provide seasonal and annual estimates of global land GPP and NPP. Due to different physiological principles, underlying assumptions, and amounts of input data, GPP predictions vary, sometimes significantly (Coops et al., 2009 this study). Although some preliminary experiments of model comparisons have been applied 
a) Meadl
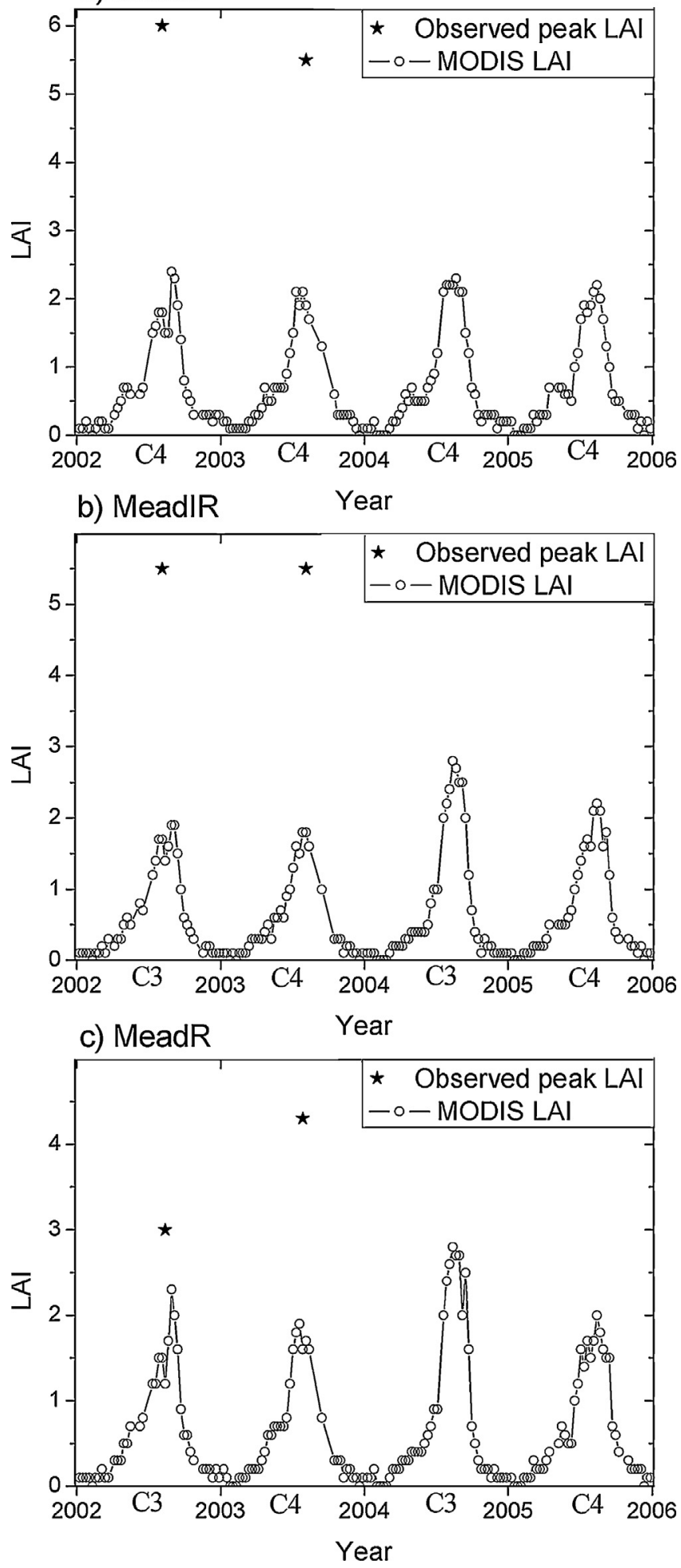

Fig. 12. Comparison of MODIS LAI and observed peak LAI (Verma et al., 2005) for C4 maize and C3 soybean at MeadI, MeadIR, and MeadR, respectively.

to evaluating model principles and uncertainties of driving forcing (Cramer et al., 1999; Ito and Sasai, 2006; Jung et al., 2007; Beer et al., 2010) a systematic inter-comparison project across available GPP models is warranted to achieve mechanistic interpretation of the disagreement of GPP predictions (Ryu et al., 2011). The evaluation of water stress factors at flux sites in this study shows that the definition of water stress factors could be the reason resulting in the significant difference of trend between different GPP products, which highlights the direction of GPP model improvements.

\section{Conclusions}

Based on current knowledge of the physiological processes of GPP, we developed and evaluated a novel terrestrial ecosystem carbon flux model (TEC) that considered both distinct difference of photosynthesis of C4 and C3 plants and water stress effect on GPP by using a coupled precipitation-driven ARTS $E$ model. The new water stress factor was defined as the ratio of actual $E-E_{\mathrm{PT}}$ and a C4/ C3 plant type-dependent $\varepsilon^{*}$ was adopted. One merit of adopting $E /$ $E_{\mathrm{PT}}$ ratio as a water stress factor in TEC GPP model is that a universal $\varepsilon^{*}$ for C3 species (including forest, crop, and grass) becomes possible. The result highlights the importance of discerning C4 and C3 plants in global GPP estimates, which implies those global GPP estimates are underestimated in part, due to the difference of C4 and C3 plants.

The evaluation of water stress factors at flux sites shows the water stress scalar $E / E_{\mathrm{PT}}$ is superior to $E / R_{\mathrm{n}}$ in representing water stress in the frame of TEC GPP model. The $f(D)$ or $f(D) \times f(\mathrm{SM})$-based water stress factor tends to exert a water stressing effect even in summer at sites featuring plentiful water supply (i.e., $f(S M)=1.0$ ) because $f(D)$ is anti-correlated with an increasing $D$, which implies that GPP models driven with a $f(D)$-based water stress factor tend to underestimate GPP trend in case of global warming, which might result in a misunderstanding of climate change impact on carbon cycle. In addition, as water stress also affects ecosystem respiration, TEC model will be developed to include respiration term so as to study the impact of water stress on ecosystem carbon balance.

Without prerequisite calibration, TEC model successfully simulated terrestrial carbon fluxes at flux sites and on a global scale with MODIS FPAR data, C4/C3 plant map, climate data, and soil data as model inputs. TEC GPP model can be easily applied to global scale. Global reanalysis meteorological data can be freely obtained through many projects such as ERA-Interim reanalysis project with a delay of a couple of months or GMAO reanalysis project in real time. MOD15A2 LAI/FPAR products and GPCC precipitation datasets are operationally processed and can be obtained without time lag. The TEC GPP model can be applied for retrospective analysis and near-real-time estimates of global land GPP and give insights to carbon cycle, water cycle, their connection and interaction with climate change.

\section{Acknowledgements}

We would like to thank the flux site investigators for providing their data through AmeriFlux program for the development of TEC GPP model. This work was supported by National Natural Science Foundation of China (41171284, 40801129), Chinese Academy of Sciences (XDA05050602-1), and partly funded by NASA Earth Science Division, as well as by the following NASA grants to H.H. Shugart: 10-CARBON10-0068, and Climate Change/09-IDS09-116. Finally the reviewers are thanked for the constructive remarks and suggestions.

\section{References}

Allen, R.G., 1998. Crop Evapotranspiration: Guidelines for Computing Crop Water Requirements. Food and Agriculture Organization of the United Nations, Rome. Asrar, G.S., Fuchs, M., Kanemasu, E.T., Hatfield, J.L., 1984. Estimating absorbed photosynthetically active radiation and leaf area index from spectral reflectance in wheat. Agron. J. 76, 300-306. 
Baldocchi, D., 1994. A comparative-study of mass and energy-exchange rates over a closed C-3 (Wheat) and an open C-4 (Corn) crop $\mathrm{CO}_{2}$ exchange and water-use efficiency. Agric. Forest Meteorol. 67, 291-321.

Baldocchi, D., Falge, E., Gu, L.H., Olson, R., Hollinger, D., Running, S., Anthoni, P., Bernhofer, C., Davis, K., Evans, R., Fuentes, J., Goldstein, A., Katul, G., Law, B., Lee, X.H., Malhi, Y., Meyers, T., Munger, W., Oechel, W., Paw, K.T., Pilegaard, K., Schmid, H.P., Valentini, R., Verma, S., Vesala, T., Wilson, K., Wofsy, S., 2001. FLUXNET: a new tool to study the temporal and spatial variability of ecosystemscale carbon dioxide, water vapor, and energy flux densities. Bull. Am. Meteorol. Soc. $82,2415-2434$.

Baldocchi, D.D., 2003. Assessing the eddy covariance technique for evaluating carbon dioxide exchange rates of ecosystems: past present and future. Glob. Change Biol. 9, 479-492.

Barnes, W.L., Pagano, T.S., Salomonson, V.V., 1998. Prelaunch characteristics of the moderate resolution imaging spectroradiometer (MODIS) on EOS-AM1. IEEE Trans. Geosci. Remote Sens. 36, 1088-1100.

Beer, C., Reichstein, M., Tomelleri, E., Ciais, P., Jung, M., Carvalhais, N., Rödenbeck, C. Arain, M.A., Baldocchi, D., Bonan, G.B., Bondeau, A., Cescatti, A., Lasslop, G. Lindroth, A., Lomas, M., Luyssaert, S., Margolis, H., Oleson, K.W., Roupsard, O., Veenendaal, E., Viovy, N., Williams, C., Woodward, F.I., Papale, D., 2010. Terrestrial gross carbon dioxide uptake: global distribution and covariation with climate. Science 329, 834-838.

Chapin, F.S., Matson, P.A., Mooney, H.A., 2002. Principles of Terrestrial Ecosystem Ecology. Springer, New York.

Chen, J.M., Mo, G., Pisek, J., Liu, J., Deng, F., Ishizawa, M., Chan, D., 2012. Effects of foliage clumping on the estimation of global terrestrial gross primary productivity. Global Biogeochem. Cy. 26 GB1019, doi:10.1029/2010gb003996.

Chen, J.Q., Davis, K.J., Meyers, T.P., 2008. Ecosystem-atmosphere carbon and water cycling in the upper Great Lakes Region. Agric. Forest Meteorol. 148 155-157.

Churkina, G., Running, S.W., Schloss, A.L., Intercomparison, P.P.N.M., 1999. Comparing global models of terrestrial net primary productivity (NPP): the importance of water availability. Global Change Biol. 5, 46-55.

Clark, K.L., Gholz, H.L., Castro, M.S., 2004. Carbon dynamics along a chronosequence of slash pine plantations in north Florida. Ecol. Appl. 14, 1154-1171.

Collatz, G.J., Ribas-Carbo, M., Berry, J.A., 1992. Coupled photosynthesis-stomatal conductance model for leaves of C4 plants. Aust. J. Plant Physiol. 19, 519-538.

Coops, N.C., Ferster, C.J., Waring, R.H., Nightingale, J., 2009. Comparison of three models for predicting gross primary production across and within forested ecoregions in the contiguous United States. Remote Sens. Environ. 113 680-690.

Cramer, W., Kicklighter, D.W., Bondeau, A., Iii, B.M., Churkina, G., Nemry, B., Ruimy, A., Schloss, A.L., et al., 1999. Comparing global models of terrestrial net primary productivity (NPP): overview and key results. Global Change Biol. 5, 1-15.

Dee, D.P., Uppala, S.M., Simmons, A.J., Berrisford, P., Poli, P., Kobayashi, S., Andrae, U., Balmaseda, M.A., Balsamo, G., Bauer, P., Bechtold, P., Beljaars, A.C.M., van de Berg, L., Bidlot, J., Bormann, N., Delsol, C., Dragani, R., Fuentes, M., Geer, A.J., Haimberger, L., Healy, S.B., Hersbach, H., Hólm, E.V., Isaksen, L., Kållberg, P., Köhler, M., Matricardi, M., McNally, A.P., Monge-Sanz, B.M., Morcrette, J.J., Park, B.K., Peubey, C., de Rosnay, P., Tavolato, C., Thépaut, J.N., Vitart, F., 2011. The ERAInterim reanalysis: configuration and performance of the data assimilation system. Q. J. Roy. Meteorol. Soc. 137, 553-597.

Desai, A.R., Noormets, A., Bolstad, P.V., Chen, J.Q., Cook, B.D., Davis, K.J., Euskirchen, E.S., Gough, C.M., Martin, J.G., Ricciuto, D.M., Schmid, H.P., Tang, J.W., Wang, W. G., 2008. Influence of vegetation and seasonal forcing on carbon dioxide fluxes across the Upper Midwest, USA: implications for regional scaling. Agric. Forest Meteorol. 148, 288-308.

Dragoni, D., Schmid, H.P., Grimmond, C.S.B., Loescher, H.W., 2007. Uncertainty of annual net ecosystem productivity estimated using eddy covariance flux measurements. J. Geophys. Res. Atmos. 112 D17102, doi:17110.11029/ 12006jd008149.

Falge, E., Baldocchi, D., Olson, R., Anthoni, P., Aubinet, M., Bernhofer, C., Burba, G. Ceulemans, R., Clement, R., Dolman, H., Granier, A., Gross, P., Grunwald, T., Hollinger, D., Jensen, N.O., Katul, G., Keronen, P., Kowalski, A., Lai, C.T., Law, B.E. Meyers, T., Moncrieff, H., Moors, E., Munger, J.W., Pilegaard, K., Rannik, U., Rebmann, C., Suyker, A., Tenhunen, J., Tu, K., Verma, S., Vesala, T., Wilson, K., Wofsy, S., 2001. Gap filling strategies for defensible annual sums of net ecosystem exchange. Agric. Forest Meteorol. 107, 43-69.

Falge, E., Baldocchi, D., Tenhunen, J., Aubinet, M., Bakwin, P., Berbigier, P., Bernhofer, C., Burba, G., Clement, R., Davis, K.J., Elbers, J.A., Goldstein, A.H., Grelle, A., Granier, A., Guomundsson, J., Hollinger, D., Kowalski, A.S., Katul, G., Law, B.E., Malhi, Y., Meyers, T., Monson, R.K., Munger, J.W., Oechel, W., Paw, K.T., Pilegaard K., Rannik, U., Rebmann, C., Suyker, A., Valentini, R., Wilson, K., Wofsy, S., 2002 Seasonality of ecosystem respiration and gross primary production as derived from FLUXNET measurements. Agric. Forest Meteorol. 113, 53-74.

Falk, M., Wharton, S., Schroeder, M., Ustin, S., Paw, K.T., 2008. Flux partitioning in an old-growth forest: seasonal and interannual dynamics. Tree Physiol. 28, 509-520.

Farquhar, G.D., Caemmerer, S., Berry, J.A., 1980. A biochemical model of photosynthetic CO2 assimilation in leaves of C3 species. Planta 149, 78-90.

Field, C.B., Randerson, J.T., Malmstrom, C.M., 1995. Global net primary production combining ecology and remote-sensing. Remote Sens. Environ. 51, 74-88.

Fung, I., Field, C.B., Berry, J.A., Thompson, M.V., Randerson, J.T., Malmström, C.M., Vitousek, P.M., Collatz, G.J., Sellers, P.J., Randall, D.A., Denning, A.S., Badeck, F., John, J., 1997. Carbon 13 exchanges between the atmosphere and biosphere. Global Biogeochem. Cy. 11, 507-533.
Gao, Y., Yu, G., Yan, H., Zhu, X., Li, S., Wang, Q., Zhang, J., Wang, Y., Li, Y., Zhao, L., Shi, P. 2014. A MODIS-based photosynthetic capacity model to estimate gross primary production in Northern China and the Tibetan Plateau. Remote Sens. Environ. $148,108-118$.

Gitelson, A.A., Peng, Y., Masek, J.G., Rundquist, D.C., Verma, S., Suyker, A., Baker, J.M., Hatfield, J.L., Meyers, T., 2012. Remote estimation of crop gross primary production with landsat data. Remote Sens. Environ. 121, 404-414.

Grant, R.F., Zhang, Y., Yuan, F., Wang, S., Hanson, P.J., Gaumont-Guay, D., Chen, J., Black, T.A., Barr, A., Baldocchi, D.D., Arain, A., 2006. Intercomparison of techniques to model water stress effects on $\mathrm{CO} 2$ and energy exchange in temperate and boreal deciduous forests. Ecol. Model. 196, 289-312.

Grant, R.F., Arkebauer, T.J., Dobermann, A., Hubbard, K.G., Schimelfenig, T.T., Suyker, A.E., Verma, S.B., Walters, D.T., 2007. Net biome productivity of irrigated and rainfed maize-soybean rotations modeling vs. measurements. Agron. J. 99, 1404-1423.

Hansen, J., Sato, M., Kharecha, P., Russell, G., Lea, D.W., Siddall, M., 2007. Climate change and trace gases. Philos. Trans. Roy. Soc. A 365, 1925-1954.

Harazono, Y., Mano, M., Miyata, A., Zulueta, R.C., Oechel, W.C., 2003. Inter-annual carbon dioxide uptake of a wet sedge tundra ecosystem in the Arctic. Tellus B 55, 215-231.

Hashimoto, H., Wang, W., Milesi, C., Xiong, J., Ganguly, S., Zhu, Z., Nemani, R., 2013. Structural uncertainty in model-simulated trends of global gross primary production. Remote Sens. 5, 1258-1273.

Heinsch, F.A., Zhao, M.S., Running, S.W., Kimball, J.S., Nemani, R.R., Davis, K.J., Bolstad, P.V., Cook, B.D., Desai, A.R., Ricciuto, D.M., Law, B.E., Oechel, W.C., Kwon, H., Luo, H.Y., Wofsy, S.C., Dunn, A.L., Munger, J.W., Baldocchi, D.D., Xu, L.K. Hollinger, D.Y., Richardson, A.D., Stoy, P.C., Siqueira, M.B.S., Monson, R.K., Burns, S.P., Flanagan, L.B., 2006. Evaluation of remote sensing based terrestrial productivity from MODIS using regional tower eddy flux network observations. IEEE Trans. Geosci. Remote Sens. 44, 1908-1925.

Houghton, J.T., Intergovernmental Panel on Climate, I., Change, Working Group, 2001. Climate change 2001: the scientific basis: contribution of Working Group I to the third assessment report of the Intergovernmental Panel on Climate Change. Cambridge University Press, Cambridge England, New York.

Huntzinger, D.N., Wei, Y., Michalak, A.M., West, T.O., Jacobson, A.R., Baker, I.T., Chen, J.M., Davis, K.J., Hayes, D.J., et al., 2012. North American Carbon Program (NACP) regional interim synthesis: trrestrial biospheric model intercomparison. Ecol. Model. 232, 144-157.

Irvine, J., Law, B.E., Hibbard, K.A., 2007. Postfire carbon pools and fluxes in semiarid ponderosa pine in central Oregon. Global Change Biol. 13, 1748-1760.

Ito, A., Sasai, T., 2006. A comparison of simulation results from two terrestrial carbon cycle models using three climate data sets. Tellus B 58, 513-522.

Jarvis, P.G., 1976. The interpretation of the variations in leaf water potential and stomatal conductance found in canopies in the field. Philos. Trans. Roy. Soc. B 593-610.

Jones, H.G., 1992. Plants and Microclimate: A Quantitative Approach to Environmental Plant Physiology. Cambridge University Press, Cambridge England, New York, USA.

Jung, M., Reichstein, M., Margolis, H.A., Cescatti, A., Richardson, A.D., Arain, M.A., Arneth, A., Bernhofer, C., Bonal, D., Chen, J., Gianelle, D., Gobron, N., Kiely, G., Kutsch, W., Lasslop, G., Law, B.E., Lindroth, A., Merbold, L., Montagnani, L., Moors, E.J., Papale, D., Sottocornola, M., Vaccari, F., Williams, C., 2011. Global patterns of land-atmosphere fluxes of carbon dioxide, latent heat, and sensible heat derived from eddy covariance, satellite, and meteorological observations. J. Geophys. Res. Biogeo. 116 G00J07, doi:10.1029/2010jg001566.

Jung, M., Vetter, M., Herold, M., Churkina, G., Reichstein, M., Zaehle, S., Ciais, P., Viovy, N., Bondeau, A., Chen, Y., Trusilova, K., Feser, F., Heimann, M., 2007. Uncertainties of modeling gross primary productivity over Europe: a systematic study on the effects of using different drivers and terrestrial biosphere models. Global Biogeochem. Cy GB4021, doi:10.1029/2006gb002915.

Kaufman, Y.J., Herring, D.D., Ranson, K.J., Collatz, G.J., 1998. Earth observing system AM1 mission to earth. IEEE Trans. Geosci. Remote Sens. 36, 1045-1055.

King, D.A., Turner, D.P., Ritts, W.D., 2011. Parameterization of a diagnostic carbon cycle model for continental scale application. Remote Sens. Environ. 115 1653-1664.

Knyazikhin, Y., Martonchik, J.V., Diner, D.J., Myneni, R.B., Verstraete, M., Pinty, B., Gobron, N., 1998. Estimation of vegetation canopy leaf area index and fraction of absorbed photosynthetically active radiation from atmosphere-corrected MISR data. J. Geophys. Res. Atmos. 103, 32239-32256.

Landsberg, J.J., Waring, R.H., 1997. A generalised model of forest productivity using simplified concepts of radiation-use efficiency carbon balance and partitioning. Forest Ecol. Manage. 95, 209-228.

Law, B.E., Falge, E., Gu, L., Baldocchi, D.D., Bakwin, P., Berbigier, P., Davis, K., Dolman, A.J., Falk, M., Fuentes, J.D., Goldstein, A., Granier, A., et al., 2002. Environmental controls over carbon dioxide and water vapor exchange of terrestrial vegetation. Agric. Forest Meteorol. 113, 97-120.

Leuning, R., Cleugh, H.A., Zegelin, S.J., Hughes, D., 2005. Carbon and water fluxes over a temperate Eucalyptus forest and a tropical wet/dry savanna in Australia: measurements and comparison with MODIS remote sensing estimates. Agric. Forest Meteorol. 129, 151-173.

Li, F.Q., Kustas, W.P., Anderson, M.C., Prueger, J.H., Scott, R.L., 2008. Effect of remote sensing spatial resolution on interpreting tower-based flux observations. Remote Sens. Environ. 112, 337-349.

Li, X., Liang, S., Yu, G., Yuan, W., Cheng, X., Xia, J., Zhao, T., Feng, J., Ma, Z., Ma, M., Liu, S., Chen, J., Shao, C., et al., 2013. Estimation of gross primary production over the terrestrial ecosystems in China. Ecol. Model. 261-262, 80-92. 
Ma, S.Y., Baldocchi, D.D., Xu, L.K., Hehn, T., 2007. Inter-annual variability in carbon dioxide exchange of an oak/grass savanna and open grassland in California. Agric. Forest Meteorol. 147, 157-171.

Maisongrande, P., Ruimy, A., Dedieu, G., Saugier, B., 1995. Monitoring seasonal and interannual variations of gross primary productivity, net primary productivity and net ecosystem productivity using a diagnostic model and remotely-sensed data. Tellus B 47, 178-190.

McCree, K.J., 1972. Test of current definitions of phtosysthetically active radiation against leaf photosysthesis data. Agric. Meteorol. 10, 442-453.

Medlyn, B.E., 2011. Comment on drought-induced reduction in global terrestrial net primary production from 2000 through 2009. Science 333, 1093.

Melillo, J.M., McGuire, A.D., Kicklighter, D.W., Moore, B., Vorosmarty, C.J., Schloss, A. L., 1993. Global climate change and terrestrial net primary production. Nature $363,234-240$.

Monteith, J.L., 1972. Solar radiation and productivity in tropical ecosystems. J. Appl. Ecol. 9, 747-766.

Monteith, J.L., 1965. Evaporation and the environment. Symp. Soc. Exp. Biol. 19, 205-234.

Monteith, J.L., 1973. Principles of Environmental Physics. Edward Arnold, London.

Mu, Q., Zhao, M., Heinsch, F.A., Liu, M., Tian, H., Running, S.W., 2007. Evaluating water stress controls on primary production in biogeochemical and remote sensing based models. J. Geophys. Res. Biogeo. 112 G01012, doi:10.1029/ 2006JG000179.

Mu, Q., Zhao, M., Kimball, J.S., McDowell, N., Running, S.W., 2013. A remotely sensed global terrestrial drought severity index. Bull. Am. Meteorol. Soc. 94, 83-98.

Myneni, R.B., Hoffman, S., Knyazikhin, Y., Privette, J.L., Glassy, J., Tian, Y., Wang, Y., Song, X., Zhang, Y., Smith, G.R., Lotsch, A., Friedl, M., Morisette, J.T., Votava, P., Nemani, R.R., Running, S.W., 2002. Global products of vegetation leaf area and fraction absorbed PAR from year one of MODIS data. Remote Sens. Environ. 83, 214-231.

Nave, L.E., Gough, C.M., Maurer, K.D., Bohrer, G., Hardiman, B., Le Moine, J., et al., 2011. Disturbance and the resilience of coupled carbon and nitrogen cycling in a north temperate forest. J. Geophys. Res. Biogeo. 116 G04016, doi: 10.1029/ 2011JG001758.

Nemani, R., Hashimoto, H., Votava, P., Melton, F., Wang, W., Michaelis, A., Mutch, L., Milesi, C., Hiatt, S., White, M., 2009. Monitoring and forecasting ecosystem dynamics using the Terrestrial Observation and Prediction System (TOPS). Remote Sens. Environ. 113, 1497-1509.

Nemani, R.R., Keeling, C.D., Hashimoto, H., Jolly, W.M., Piper, S.C., Tucker, C.J., Myneni, R.B., Running, S.W., 2003. Climate-driven increases in global terrestrial net primary production from 1982 to 1999. Science 300, 1560-1563.

Nightingale, J.M., Coops, N.C., Waring, R.H., Hargrove, W.W., 2007. Comparison of MODIS gross primary production estimates for forests across the U.S.A. with those generated by a simple process model 3-PGS. Remote Sens. Environ. 109, 500-509.

Pau, S., Edwards, E.J., Still, C.J., 2013. Improving our understanding of environmental controls on the distribution of C3 and C4 grasses. Global Change Biol. 19, 184-196.

Paw, K.T., Baldocchi, D.D., Meyers, T.P., Wilson, K.B., 2000. Correction of eddycovariance measurements incorporating both advective effects and density fluxes. Bound-Lay Meteorol. 97, 487-511.

Pearcy, R.W., Ehleringer, J., 1984. Comparative ecophysiology of C3 and C4 plants. Plant Cell Environ. 7, 1-13.

Penman, H.L., 1948. Natural evaporation from open water: bare soil and grass. Proc. R. Soc. Lond. Ser. A 193, 120-146.

Potter, C.S., Randerson, J.T., Field, C.B., Matson, P.A., Vitousek, P.M., Mooney, H.A., Klooster, S.A., 1993. Terrestrial ecosystem production - a process model-based on global satellite and surface data. Global Biogeochem. Сy. 7, 811-841.

Priestley, C.H., Taylor, R.J., 1972. Assessment of surface heat-flux and evaporation using large-scale parameters. Mon. Weather Rev. 100, 81-92.

Prince, S.D., Goward, S.N., 1995. Global primary production: a remote sensing approach. J. Biogeogr. 22, 815-835.

Rahman, A.F., Sims, D.A., Cordova, V.D., El-Masri, B.Z., 2005. Potential of MODIS EVI and surface temperature for directly estimating per-pixel ecosystem C fluxes. Geophys. Res. Lett. 32 L19404, doi:19410.11029/12005gl024127.

Raich, J.W., Rastetter, E.B., Melillo, J.M., Kicklighter, D.W., Steudler, P.A., Peterson, B. J., Grace, A.L., Moore, B., Vorosmarty, C.J., 1991. Potential net primary productivity in South-America - application of a global model. Ecol Appl. 1, 399-429.

Rudolf, B.,Becker, A., Schneider, U., Meyer-Christoffer, A., and Ziese, M., 2011. New Full Data Reanalysis Version 5 provides high-quality gridded monthly precipitation data. Global Energy and Water Cycle Experiment (GEWEX) News, 21, 4-5.

Ruimy, A., Dedieu, G., Saugier, B., 1996. TURC: a diagnostic model of continental gross primary productivity and net primary productivity. Global Biogeochem. Су. 10, 269-285.

Ruimy, A., Saugier, B., Dedieu, G., 1994. Methodology for the estimation of terrestrial net primary production from remotely sensed data. J. Geophys. Res. Atmos. 99, 5263-5283.

Running, S.W., Nemani, R.R., Heinsch, F.A., Zhao, M.S., Reeves, M., Hashimoto, H., 2004. A continuous satellite-derived measure of global terrestrial primary production. Bioscience 54, 547-560.

Running, S.W., Thornton, P.E., Nemani, R., Glassy, J.M., 2000. Global terrestrial gross and net primary productivity from the earth observing system. In: Sala, O.E., Jackson, R.B., Mooney, H.A., Howarth, R.W. (Eds.), Methods in Ecosystem Science. Springer, New York, pp. 421-453.
Ryu, Y., Baldocchi, D.D., Ma, S., Hehn, T., 2008. Interannual variability of evapotranspiration and energy exchange over an annual grassland in California. J. Geophys. Res. Atmos D09104, doi:9110.01029/02007jd009263.

Ryu, Y., Baldocchi, D.D., Kobayashi, H., van Ingen, C., Li, J., Black, T.A., Beringer, J., van Gorsel, E., Knohl, A., Law, B.E., Roupsard, O., 2011. Integration of MODIS land and atmosphere products with a coupled-process model to estimate gross primary productivity and evapotranspiration from $1 \mathrm{~km}$ to global scales. Global Biogeochem. Cy. 25 GB4017, doi:10.1029/2011GB004053.

Samanta, A., Costa, M.H., Nunes, E.L., Vieira, S.A., Xu, L., Myneni, R.B., 2011. Comment on drought-induced reduction in global terrestrial net primary production from 2000 through 2009. Science 333, 1093.

Sasai, T., Okamoto, K., Hiyama, T., Yamaguchi, Y., 2007. Comparing terrestrial carbon fluxes from the scale of a flux tower to the global scale. Ecol. Model. 208, 135-144.

Scott, R.L., Jenerette, G.D., Potts, D.L., Huxman, T.E., 2009. Effects of seasonal drought on net carbon dioxide exchange from a woody-plant-encroached semiarid grassland. J. Geophys. Res. Atmos. 114 G04004, doi:10.1029/2008JG000900.

Sheridan, P.J., Delene, D.J., Ogren, J.A., 2001. Four years of continuous surface aerosol measurements from the department of energy's atmospheric radiation measurement program Southern Great Plains cloud and radiation testbed site. J Geophys. Res. Atmos. 106, 20735-20747.

Sims, D.A., Rahman, A.F., Cordova, V.D., El-Masri, B.Z., Baldocchi, D.D., Bolstad, P.V., Flanagan, L.B., Goldstein, A.H., Hollinger, D.Y., Misson, L., Monson, R.K., Oechel, W.C., Schmid, H.P., Wofsy, S.C., Xu, L., 2008. A new model of gross primary productivity for North American ecosystems based solely on the enhanced vegetation index and land surface temperature from MODIS. Remote Sens. Environ. 112, 1633-1646.

Sjöström, M., Zhao, M., Archibald, S., Arneth, A., Cappelaere, B., Falk, U., de Grandcourt, A., Hanan, N., Kergoat, L., Kutsch, W., Merbold, L., Mougin, E. Nickless, A., Nouvellon, Y., Scholes, R.J., Veenendaal, E.M., Ardö, J., 2013. Evaluation of MODIS gross primary productivity for Africa using eddy covariance data. Remote Sens. Environ. 131, 275-286.

Still, C.J., Berry, J.A., Collatz, G.J., DeFries, R.S., 2003. Global distribution of C3 and C4 vegetation: carbon cycle implications. Global Biogeochem. Сy. 17, 1006. doi: http://dx.doi.org/10.1029/2001gb001807.

Suyker, A.E., Verma, S.B., 2008. Interannual water vapor and energy exchange in an irrigated maize-based agroecosystem. Agric. Forest Meteorol. 148, 417-427.

Tan, B., Woodcock, C.E., Hu, J., Zhang, P., Ozdogan, M., Huang, D., Yang, W. Knyazikhin, Y., Myneni, R.B., 2006. The impact of gridding artifacts on the local spatial properties of MODIS data: implications for validation, compositing, and band-to-band registration across resolutions. Remote Sens. Environ. 105, 98-114.

Thomas, C.K., Law, B.E., Irvine, J., Martin, J.G., Pettijohn, J.C., Davis, K.J., 2009. Seasonal hydrology explains interannual and seasonal variation in carbon and water exchange in a semiarid mature ponderosa pine forest in central Oregon. J. Geophys. Res. Atmos. 114 G04006, doi:10.1029/2009JG001010.

Thornthwaite, C.W., 1948. An approach toward a rational classification of climate. Geogr. Rev. 38, 55-94.

Turner, D.P., Urbanski, S., Bremer, D., Wofsy, S.C., Meyers, T., Gower, S.T., Gregory, M., 2003. A cross-biome comparison of daily light use efficiency for gross primary production. Global Change Biol. 9, 383-395.

Turner, D.P., Ritts, W.D., Maosheng, Z., Kurc, S.A., Dunn, A.L., Wofsy, S.C., Small, E.E. Running, S.W., 2006. Assessing interannual variation in MODIS-based estimates of gross primary production. IEEE Trans. Geosci. Remote Sens. 44, 1899-1907.

Verma, S.B., Dobermann, A., Cassman, K.G., Walters, D.T., Knops, J.M., Arkebauer, T.J. Suyker, A.E., Burba, G.G., Amos, B., Yang, H.S., Ginting, D., Hubbard, K.G., Gitelson, A.A., Walter-Shea, E.A., 2005. Annual carbon dioxide exchange in irrigated and rainfed maize-based agroecosystems. Agric. Forest Meteorol. 131, 77-96

Veroustraete, F., Sabbe, H., Eerens, H., 2002. Estimation of carbon mass fluxes over Europe using the C-Fix model and Euroflux data. Remote Sens. Environ. 83, 376-399.

Verstraeten, W.W., Veroustraete, F., Feyen, J., 2006. On temperature and water limitation of net ecosystem productivity: implementation in the C-Fix model. Ecol. Model. 199, 4-22.

Wang, Q., Tenhunen, J., Falge, E., Bernhofer, C., Granier, A., Vesala, T., 2004. Simulation and scaling of temporal variation in gross primary production for coniferous and deciduous temperate forests. Global Change Biol. 10, 37-51.

Waring, R.H., Law, B.E., Goulden, M.L., Bassow, S.L., McCreight, R.W., Wofsy, S.C. Bazzaz, F.A., 1995. Scaling gross ecosystem production at Harvard Forest with remote sensing: a comparison of estimates from a constrained quantum-use efficiency model and eddy correlation. Plant Cell Environ. 18, $1201-1213$.

Willmott, C.J., Rowe, C.M., Philpot, W.D., 1985. Small-scale climate maps: a sensitivity analysis of some common assumptions associated with grid-point interpolation and contouring. Cartogr. Geogr. Inf. 12, 5-16.

Wu, C., Chen, J.M., Huang, N., 2011. Predicting gross primary production from the enhanced vegetation index and photosynthetically active radiation: evaluation and calibration. Remote Sens. Environ. 115, 3424-3435.

Xiao, J., Zhuang, Q., Baldocchi, D.D., Law, B.E., Richardson, A.D., Chen, J., et al., 2008 Estimation of net ecosystem carbon exchange for the conterminous United States by combining MODIS and AmeriFlux data. Agric. Forest Meteorol. 148, 1827-1847. 
Xiao, J., Zhuang, Q., Law, B.E., Chen, J., Baldocchi, D.D., Cook, D.R., Oren, R., Richardson, A.D., Wharton, S., Ma, S., Martin, T.A., Verma, S.B., Suyker, A.E., Scott R.L., Monson, R.K., Litvak, M., Hollinger, D.Y., Sun, G., Davis, K.J., Bolstad, P.V., Burns, S.P., Curtis, P.S., Drake, B.G., Falk, M., Fischer, M.L., Foster, D.R., Gu, L., Hadley, J.L., Katul, G.G., Matamala, R., McNulty, S., Meyers, T.P., Munger, J.W., Noormets, A., Oechel, W.C., Paw, U., Schmid, K.T., Starr, H.P., Torn, G., Wofsy, M.S. 2010. A continuous measure of gross primary production for the conterminous United States derived from MODIS and AmeriFlux data. Remote Sens. Environ. $114,576-591$.

Xiao, X., Zhang, Q., Hollinger, D., Aber, J., Moore, B., 2005a. Modeling gross primary production of an evergreen needleleaf forest using MODIS and climate data. Ecol. Appl. 15, 954-969.

Xiao, X., Zhang, Q., Saleska, S., Hutyra, L., De Camargo, P., Wofsy, S., Frolking, S., Boles, S., Keller, M., Moore Iii, B., 2005b. Satellite-based modeling of gross primary production in a seasonally moist tropical evergreen forest. Remote Sens. Environ. 94, 105-122.

Yan, H., Shugart, H.H., 2010. An air relative-humidity-based evapotranspiration model from eddy covariance data. J. Geophys. Res. Atmos. 115 D16106, doi:10.1029/2009jd013598.

Yan, H., Wang, S.Q., Billesbach, D., Oechel, W., Zhang, J.H., Meyers, T., Martin, T.A. Matamala, R., Baldocchi, D., Bohrer, G., Dragoni, D., Scott, R., 2012. Global estimation of evapotranspiration using a leaf area index-based surface energy and water balance model. Remote Sens. Environ. 124, 581-595.

Yan, H., Yu, Q., Zhu, Z.-C., Myneni, R.B., Yan, H.-M., Wang, S.-Q., Shugart, H.H., 2013. Diagnostic analysis of interannual variation of global land evapotranspiration over 1982-2011: assessing the impact of ENSO. J. Geophys. Res. Atmos. 118, 8969-8983.

Yang, F.H., Ichii, K., White, M.A., Hashimoto, H., Michaelis, A.R., Votava, P., Zhu, A.X Huete, A., Running, S.W., Nemani, R.R., 2007. Developing a continental-scale measure of gross primary production by combining MODIS and AmeriFlux data through Support Vector Machine approach. Remote Sens. Environ. 110, 109-122.

Yang, W., Shabanov, N.V., Huang, D., Wang, W., Dickinson, R.E., Nemani, R.R., Knyazikhin, Y., Myneni, R.B., 2006. Analysis of leaf area index products from combination of MODIS Terra and Aqua data. Remote Sens. Environ. 104, 297-312.

Yang, Y., Shang, S., Guan, H., Jiang, L., 2013. A novel algorithm to assess gross primary production for terrestrial ecosystems from MODIS imagery. J. Geophys. Res. Biogeo. 118, 590-605.

Yang, Y., Guan, H., Shang, S., Long, D., Simmons, C.T., 2014. Toward the use of the MODIS ET product to estimate terrestrial GPP for nonforest ecosystems. IEEE Geosci. Remote Sens. 11, 1624-1628.

Yuan, W., Liu, S., Yu, G., Bonnefond, J.-M., Chen, J., Davis, K., Desai, A.R., Goldstein, A. H., Gianelle, D., Rossi, F., Suyker, A.E., Verma, S.B., 2010. Global estimates of evapotranspiration and gross primary production based on MODIS and global meteorology data. Remote Sens. Environ. 114, 1416-1431.

Yuan, W.P., Liu, S., Zhou, G.S., Zhou, G.Y., Tieszen, L.L., Baldocchi, D., Bernhofer, C., Gholz, H., Goldstein, A.H., Goulden, M.L., Hollinger, D.Y., Hu, Y., Law, B.E., Stoy, P. C., Vesala, T., Wofsy, S.C., Collaborators, A., 2007. Deriving a light use efficiency model from eddy covariance flux data for predicting daily gross primary production across biomes. Agric. Forest Meteorol. 143, 189-207.

Zhang, Y.Q., Yu, Q., Jiang, J., Tang, Y.H., 2008. Calibration of Terra/MODIS gross primary production over an irrigated cropland on the North China Plain and an alpine meadow on the Tibetan Plateau. Global Change Biol. 14, 757-767.

Zhao, M.S., Running, S.W., 2010. Drought-induced reduction in global terrestrial net primary production from 2000 through 2009. Science 329, 940-943.

Zhao, M.S., Heinsch, F.A., Nemani, R.R., Running, S.W., 2005. Improvements of the MODIS terrestrial gross and net primary production global data set. Remote Sens. Environ. 95, 164-176. 